Illinois State University

ISU ReD: Research and eData

Theses and Dissertations

$10-6-2016$

\title{
Asian Anxieties and Alliances: Balancing the Rise of China
}

Adam David Crank

Illinois State University, adamcrank2@outlook.com

Follow this and additional works at: https://ir.library.illinoisstate.edu/etd

Part of the International Relations Commons

\section{Recommended Citation}

Crank, Adam David, "Asian Anxieties and Alliances: Balancing the Rise of China" (2016). Theses and Dissertations. 611.

https://ir.library.illinoisstate.edu/etd/611

This Thesis is brought to you for free and open access by ISU ReD: Research and eData. It has been accepted for inclusion in Theses and Dissertations by an authorized administrator of ISU ReD: Research and eData. For more information, please contact ISUReD@ilstu.edu. 
ASIAN ANXIETIES AND ALLIANCES:

BALANCING THE RISE OF CHINA

\section{Adam Crank}

\section{Pages}

China's rise has been met with both hope and apprehension. However, with its recent actions in the South and East China Seas, surrounding nations are becoming increasingly concerned that China may have expansionist or even hegemonic ambitions. China has taken what many of these countries consider to be aggressive actions in the past several years and months. One of the main questions now is how the surrounding nations, as well as the United States, will react to China's actions. As of now diplomatic means of failed to resolve the crisis in the South and East China Seas.

This thesis will document the diplomatic means that have been utilized in vain by China's neighbors before asking whether or not those nations which surround China may choose to form an alliance in order to offset its increasingly aggressive rise. Specifically, we will examine the challenges inherent to forming such an organization in the region and contrast our hypothetical Asian-Pacific alliance with the NATO alliance in Europe. We hope to contribute to the current discussion and literature surrounding the rise of China from a Structural Realist perspective.

KEYWORDS: China, Realism, Structural Realism, NATO, Alliance, Asia-Pacific, Asia, Japan, Philippines, South China Sea, East China Sea, Artificial Islands, Permanent Court of Arbitration 


\section{ASIAN ANXIETIES AND ALLIANCES:}

BALANCING THE RISE OF CHINA

ADAM CRANK

A Thesis Submitted in Partial Fulfillment of the Requirements for the Degree of

MASTER OF SCIENCE

Department of Politics and Government

\section{ILLINOIS STATE UNIVERSITY}


(C) 2016 Adam Crank 


\title{
ASIAN ANXIETIES AND ALLIANCES:
}

BALANCING THE RISE OF CHINA

\author{
ADAM CRANK
}

COMMITTEE MEMBERS:

Michaelene Cox, Chair

Sherri Replogle

T. Y. Wang 


\section{ACKNOWLEDGMENTS}

The writer wishes to thank first and foremost his parents who have steadfastly encouraged and supported him through the writing of this thesis. Dr. Wesley Phelan, formerly of Eureka College who mentored and guided him throughout his undergraduate career. Dr. Codrin Nedita, also formerly of Eureka college, who instilled in him a love of economics. Last but not least the writer would like to thank his thesis committee, including Dr. T. Y. Wang and Dr. Sherri Replogle, and especially his committee chair Dr. Michaelene Cox for her time and commitment as well as her guidance throughout the entire process.

A. C. 


\section{CONTENTS}

\section{Page}

ACKNOWLEDGMENTS

CONTENTS

FIGURES

CHAPTER I: STATING THE CASE

Introduction

Historical Background

Theoretical Framework

Literature Review

The ASEAN View

De-emphasizing the United States

Emphasizing the United States

Methodology

CHAPTER II: THE CHALLENGES

Old NATO, Old Challenges

Challenges of a 21st Century Asian Pacific NATO

Challenge \#1: Hub and Spoke Sufficiency

Challenge \#2: The Tale of Two Yurei, or the Tale of Two Ghosts

Challenge \#3: Straw that Broke the Eagle's Back 
$\begin{array}{ll}\text { CHAPTER III: THE SOLUTIONS } & 68\end{array}$

$\begin{array}{ll}\text { Old NATO, Old Solutions } & 68\end{array}$

$\begin{array}{ll}\text { Solutions for a 21st Century Asian-Pacific NATO } & 70\end{array}$

$\begin{array}{ll}\text { Hub and Spoke Solution } & 70\end{array}$

$\begin{array}{ll}\text { Two Yurei Solution } & 74\end{array}$

$\begin{array}{ll}\text { The Eagle's Back Solution } & 77\end{array}$

The Nine Dash Solution $\quad 82$

Blow Back Solution $\quad 85$

$\begin{array}{ll}\text { CHAPTER IV: DISCUSSION } & 87\end{array}$

$\begin{array}{ll}\text { Conclusion } & 93\end{array}$

REFERENCES 96 


\section{FIGURES}

Figure $\quad$ Page

1. South China Sea Claims (Mirski, 2015) 5 


\section{CHAPTER I: STATING THE CASE}

In this first chapter, we will introduce the thesis and our thesis question. Next, we will study the historical background of the region which we are studying. Following that section we will examine the theoretical basis of our thesis before moving on to current literature. Finally, we will explain our methodology before the beginning of the second chapter.

\section{Introduction}

Today, in the Asian-Pacific region, it seems as if a new Cold War is heating up. Within that region, China is defying international law by making claims to, and seizing, the territory of its neighbors in the South China Sea. Its unprecedented and aggressive actions have not only shocked the world, but are precipitating a diplomatic crisis. In a move to reassure allies and confront China, the United States has attempted to dissuade China through diplomatic and nonviolent military means. Likewise, regional nations have begun to take actions to strengthen their territorial holdings and military footing. Much like the Soviet Union of the 20th century, China is emerging as the 21 st century adversary of the United States and its Asian-Pacific allies. But how will the United States and the nations of the Asian-Pacific region respond to the emerging Chinese threat and the volatile crisis of the South China Sea? How can the scales of power be balanced? Could these Asian nations and the United States choose, as their European predecessors did with NATO, to build a military alliance? And if they did, what would be the challenges inherent in building such a military, NATO-type alliance in the Asian-Pacific region?

To better answer this question, it is useful to return to the original Cold War and an original Cold Warrior who called for the original NATO alliance.

Winston Churchill was, without a doubt, one of the greatest visionary statesmen of the 20th century. He was a man who possessed the ability to see far into the future, predicting the 
outcome of events that would take years to materialize. Churchill began his fortune telling career by predicting the rise of Nazi Germany and the eventual conflict that would unfold. At the time, his contemporaries thought him both brash and melodramatic; they proclaimed "peace in our time" (Chamberlain, 1938). However, following the great slaughter of more than fifty million people, he had earned the respect, and the ears, of not only his fellow countrymen but of the world as well. Thus, it was with great anticipation in 1946 that American and British statesmen and even the President of the United States, gathered at Westminster College to hear the old Prime Minister offer up one more sobering prediction (Manchester, 2013).

This new prophecy foresaw the Soviet Union-until that time considered an ally of the West-as an emerging adversary and enemy of the United States and the Western world in general. During the Second World War, the Soviet Union had proved to be an invaluable partner, smashing the German war machine, rolling back the Nazi invasion of Eastern Europe, and capturing the last Nazi stronghold, the capital city of Berlin. However, following the end of the war, democratic and Western allies of Stalin's Soviet state came to realize they had made a deal with the devil. While the United States demobilized and sent home millions of soldiers, its Russian counterpart did not, leaving the smoldering ruins of Europe a veritable open henhouse (Manchester, 2013).

Following one diplomatic crisis after another, relations between the United States and the Soviet Union slowly deteriorated until they reached a crisis point. The Soviets had been subversively extending and consolidating their control over Eastern Europe through local communist parties and corrupt officials. However, when Soviet forces blockaded Berlin and refused to let Allied forces enter, it was the last straw. 
Seeing the fall of Eastern Europe to the Soviets and not wanting to exchange an Iron Cross for an Iron Curtain, the Western democracies of Europe, including Great Britain and France, signed the Treaty of Brussels. This treaty compelled each signatory nation to come to the defense of any other member country should that nation be invaded or attacked. However, the treaty's guarantee rang hollow as, absent the aid of the United States, no country in Europe could hope to stand up to the might of the Soviet Empire. But Churchill had foreseen the vacuum that was present in Europe and the need for the United States to fill it. In his famous Iron Curtain speech, he implored America to take up the mantel left by the British Empire and to protect the Western world through an American-led alliance of European democracies. Thus, in 1949 the United States met the challenge given to them by Churchill, facing down the Soviet Union and securing Europe by creating the North Atlantic Treaty Organization (NATO). For forty years, NATO provided the continent with a collective security guarantee whereby each member nation would treat an attack on another member as if they themselves had been attacked. NATO standardized militaries, strategies, and command structures used to fight the Cold War and provided a potent deterrent against any Soviet aggression. And though these signatory nations came close several times to an all-out war with the Soviets, the NATO alliance and its deterrents proved to be too powerful to challenge directly (Mastney, 2006).

Today, the Soviet threat which once menaced Europe is no more than a memory, and many would argue that while NATO was once fantastically successful, it has now outlived its mission. And yet, if Churchill were alive today, he might once again make a prediction, and this time he would be pointing to an entirely different region of the globe. In South East Asia, a new drama-like the Soviet drama of old-is playing out and becoming more and more fractious by the day. And while the setting is different and the players have changed, the story is still the same. 
The South and East China Seas are the new arenas of conflict, and within them, an aggressive China is unilaterally enforcing its will on the region. This emerging conflict centers on maritime sovereignty in these seas, with the countries that populate these waters each bringing separate and competing claims. Here, instead of territory being demarcated by clearly defined borders, the region is a crazy quilt of overlapping and competing claims. While most of these claims have existed for more than a century without significant conflict, this issue has recently and rapidly come to a head with the unchecked and hostile actions of the People's Republic of China (CFR, 2016). 


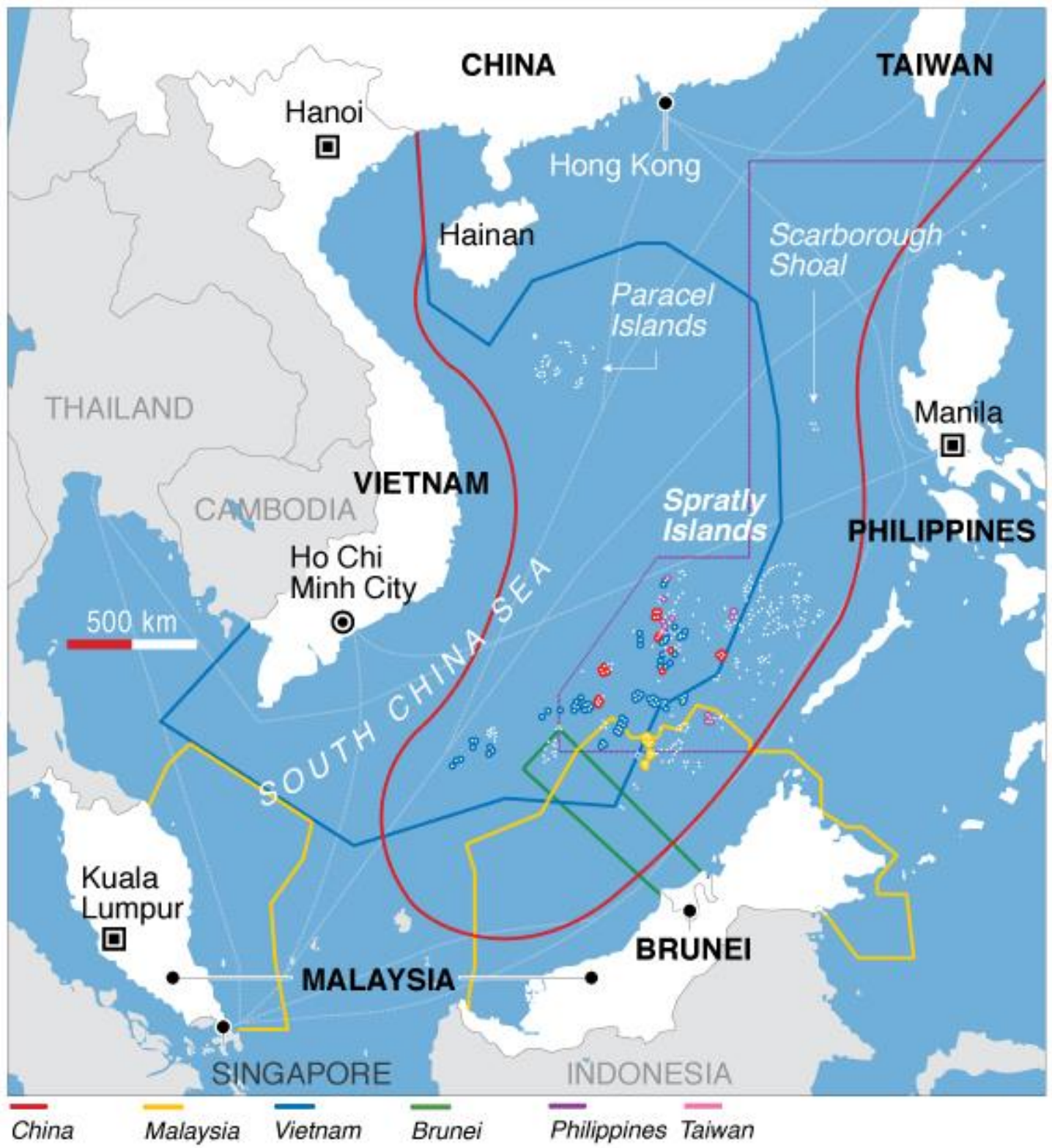

Figure 1. South China Sea Claims. Reprinted from "Dispute in the South China Sea: a Legal Primer" Mirsky S., In LawFare, 2015, Retrieved October 15, 2016 from https://www.lawfare.com/dispute-south-china-sea-legal-primer

In the South China Sea, which is the main theater of contention and the one with the largest number of claimants, China has asserted its claim to the lion's share of that water world. It does this by appealing to ancient fishing traditions and hundred-year-old maps depicting a 
nine-dash territorial line which scallops more than ninety percent of the South China Sea. Unfortunately, this nine-dash line intersects almost every other nation's territorial claims, claims largely based on post-war maritime law. Thus, for well over fifty years, these South East Asian countries have been deadlocked over how to resolve their competing claims, but the disagreements have never escalated significantly. But the world at large, and that region in particular, has changed dramatically within these last fifty years. In that span of time, South East Asia has emerged as a global center of production and trade. With more than $\$ 5.3$ trillion dollars of trade and millions of barrels of oil passing through these waters every year, this once regional dispute has morphed into an issue with global implications. Additionally, the region is host to a tremendous amount of natural resources and is geographically strategic as well. And that is, perhaps, why China is done waiting for diplomatic solutions and has asserted its dominance in the region in a way never before seen in modern times (CFR, 2016).

While decades ago there were brief conflicts over the small islands and reefs that dot the South China Sea, by the 1980's the situation had largely stabilized with only a peppering of subsequent episodes (Navarro, 2015). Yet recently, in the last five to six years, China has escalated tensions to levels never before seen. This new round of contention over the sea and regional boundaries began anew with China attempting to strengthen its territorial claims by shadowing and harassing US Naval warships and planes, as well as the oil and fishing vessels of other surrounding nations. US Navy Surveillance ships have been routinely intercepted and, at times, their sophisticated towed sonar arrays have been damaged by Chinese submarines (Starr, 2009). Likewise, US military planes were, and still are, intercepted and shadowed. In 2012 China took the startling step of seizing Scarborough Shoal, a submerged reef, from the Philippines. It has since been shut off from Philippine naval, coast guard and fishing vessels. But the real tour 
de force has been the capture and transformation of many other contested underwater reefs throughout the region into new, sandy islands (CFR, 2016).

The Tian Jing Hao, the largest dredging ship in Asia, is a modern marvel of engineering. This German-designed dredger, accompanied by hundreds of barges, has sucked up and piled thousands of tons of sand atop at least seven reefs in the South China Sea, thus making them into new de-facto Chinese islands. This ambitious Chinese strategy to assert dominion over the South China Sea has truly accelerated the once stagnant territorial conflict into a fast-paced, diplomatic nightmare. But as the sand has settled, this protracted conflict has not. On the contrary, even though China has been solidifying its territorial claims with these projects, it has continued to escalate tensions in other more threatening ways (CFR, 2016).

In the East China Sea, the region above the South China Sea, China has recently and arbitrarily declared an air defense zone where there had previously been none-an air zone that conveniently overlaps islands in that region which China now claims. In a further escalation of tensions, it has come to light that anti-ship missiles have been installed on older, more established Chinese islands in the South China Sea. To many observers this is an indication that China intends to militarize its new islands as well and, in doing so, the entire South China Sea region would then become a militarized and potentially dangerous new territory completely controlled by China (Panda, 2016).

In the face of Beijing's my way or the highway attitude, neighboring nations in the region have thus far attempted to resolve the emerging crisis by diplomatic and legal routes. The longstanding arbiter of this conflict has been the Association of South East Asian Nations (ASEAN). ASEAN is a regional economic pact which includes every claimant of the South China Sea, except for China and Taiwan. While ASEAN is primarily an economic association, it 
has a long history of successfully arbitrating conflicts in the region (Chia, 2015). Despite this, the organization has had little to no success in convincing China to peacefully resolve its disputes in the region. This is in large part due to infighting within the organization. ASEAN members Cambodia and Laos, which maintain close diplomatic and economic ties with China and have consistently taken its side, are in direct conflict with other member nations who have competing claims with China. In fact, the deadlock within the organization has become so bad that following a recent meeting in Cambodia with Chinese diplomats to discuss contentious issues related the South China Sea, the meeting failed to release a joint statement, something that has not happened once in the organization's forty-plus year history (Palatino, 2015). But perhaps the most damning bellwether of ASEAN's inability to effectively resolve the disputes in the South China Sea was its almost immediate retraction of several statements that appeared to rebuke China's heavy-handed tactics. ASEAN, “expressed our (ASEAN's) serious concerns over recent and ongoing developments, which have eroded trust and confidence, increased tensions and which may have the potential to undermine peace, security and stability in the South China Sea." The retraction of these tepid statements, which did not even single out China, occurred only hours after the statements had been released to the public (Thayer, 2016a). Furthermore, sources within ASEAN confirmed that Chinese diplomates heavily pressured ASEAN officials to retract the statements (Beech, 2016). It is clear that ASEAN is more concerned with preserving markets than it is with the territorial integrity of its member states. Yet while ASEAN continues to walk on diplomatic egg shells, Beijing continues to smash them. For instance, at the recent Shangri La dialogues, a regional forum created as a means of encouraging communication between various Asian countries, China adopted a strident and inflexible tone, loudly reasserting its supposedly immutable claim to the South China Sea (WONG, 2016). Perhaps the final nail in the coffin for a 
diplomatic solution has been China's refusal to accept the July 2016 ruling of the Permanent Court of Arbitration in its judgement of China and the Philippine's competing South China Sea claims (PRC, 2016). The court, a long established and respected institution, predating even the United Nations, took up the dispute when the Philippines brought the case before them. In a stunning landmark ruling, the court unanimously rejected China's historic-based claims to the South China Sea. Yet, despite being a party to the court and formally recognizing its legitimacy, the Chinese government has thus far refused to recognize the ruling (Phillips, 2016). The rejection of this tried and true historic method of resolving international disputes is certainly troubling, and must leave observers contemplating the likelihood of a diplomatic solution to the South China Sea dispute. This is a new reality, one which forces the remaining Asian-Pacific states to contemplate their responses to mounting Chinese aggression.

With the door to dialogue seemingly slammed shut, the remaining states have begun to talk to one another. Military ties between these regional nations are being strengthened, and cooperation with the United States is increasing. Japan, a key player in the regional disputes and an emerging adversary of China, has strengthened its ties to nations such as the Philippines and Vietnam by selling them military hardware and participating in regional wargames (Sekiguchi, 2015). The United States, likewise, is strengthening and reaffirming its ties to the region in an effort to strengthen its position there and reassure regional allies. Vietnam is drawing closer to its former enemy the United States, and has been exempted from a long standing US weapons embargo in an apparent move to strengthen that country's defenses (Harris, 2016). Even nations such as India, that are seemingly removed from the emerging conflict, nevertheless feel the press of China, and are strengthening their ties in the region (Parrikar, 2016). Thus, in the countries surrounding the South and East China Seas, one can see the emerging outline of a great 
balancing act taking place as threatened countries begin to band together against a common threat. In fact, the Asian-Pacific region may well be seeing the embryonic stages of a NATOtype alliance forming against China. The European NATO, while maintaining ties with various countries in the region, does not claim any Asian-Pacific countries as members. This is understandable as NATO's official and historical mission has centered almost exclusively on Europe. Furthermore, few if any scholars see the role of European NATO expanding outside of this sphere. Thus, in the absence of an expansion of the European NATO the nations of East and Southeast Asia may find that a military alliance is one of their only recourses against an intransigent China. But what are the real world obstacles to get from point A to point B? That is to ask, what are the challenges the nations of the Asia-Pacific region would face in forming their own version of NATO?

To answer this question, we will need to break down our discussion into it several distinct sections. First, in order to ground the proceeding discussion, we will first delve into the economic, military and societal history of the region over the past two hundred years. From there we will examine the current academic and theoretical literature on alliances and the efforts to manage the rise of China in the Asia-Pacific region. Subsequently, a brief discussion of the methodology used will then be followed by series of challenges that would confront nations attempting to build an Asian-Pacific alliance. Throughout the paper we will compare and contrast the original European NATO with our new hypothetical Asian-Pacific NATO. In doing this, we will be able to better understand the challenges facing any prospective Asian-Pacific alliance while looking to history for solutions to those challenges. At the end of the paper, we hope to have a more comprehensive understanding of the Asian-Pacific region, the rise of China, 
and the unique challenges that make the forming of a military defense-pact in the Asian-Pacific region different than the formation of other military alliances in regions such as Europe.

\section{Historical Background}

One could review thousands of years of Asian-Pacific history, but for the purposes of this discussion, we will focus on the broad, sweeping historical events of the last two hundred years. The reverberations from that period are still felt today and have, to a large extent, shaped the conflict as it is today. In the time before this period, Asia, and especially China, was host to one of the greatest and most advanced empires of antiquity. Trade and culture flourished during that time and China prospered as a result. Yet during the 19th century, in one of its more inwardfacing periods, China enacted strict trading laws, demanding only silver in exchange for its highly coveted goods. British merchants, unwilling to pay this heavy price, circumvented this defacto tax by engaging in the lucrative trade of opium. Outraged, the Chinese cracked down on the illegal trade, which ultimately led to a war with the British Empire. The British were victorious in this first Opium War, and forced their defeated rivals to reform their trading policies, legalize the market for opium, and pay for war damages. The end of this first Opium War also marked the beginning of the so-called "Century of Humiliation" during which China was subjected to a slew of what they labeled as "unfair treaties" and other forms of foreign intervention. It was this period that would permanently scar the Chinese psyche and become a source of shame and anger for generations to come (Navarro, 2015). But not every nation in Asia suffered through trade with the West. Some, in fact, prospered and thrived from it.

To the east of China, the isolated, feudal country of Japan-seemingly stuck in a medieval time warp-received a surprising wakeup call from the American Navy commander Commodore Perry. Perry, whose heavily armed naval flotilla blockaded the then-Japanese capital of Edo, 
gave the Japanese an ultimatum: open your county to trade or else. Left with no alternatives, the Japanese accepted this ultimatum. But seeing how their neighbors to the West had effectively lost their sovereignty to the colonial nations of Europe, the Japanese approached trade somewhat differently. Instead of attempting to stall or retard the opening of their country to trade, the Japanese embraced both trade with the West and modernity with open arms. This period, known as the Meiji Restoration, saw legions of young Japanese men sent to Europe so that Japan could learn the secrets of the West and, thus, replicate them. And with this replication came the rapid and breathtaking modernization of Japan into a formidable Asian power. Even today, Japan is characterized by its economic dominance and dynamism. And in contrast to its Chinese neighbor, Japan maintains a closer relationship to the West established through generations of open markets and free trade (Walker B., 2015).

The contrast between China and Japan soon bifurcated into a gaping chasm. Widened by the former's hopelessly backward ways and the latter's deft mastery of the ultramodern, this split was nowhere better demonstrated than during the first Sino-Japanese war of 1894. When Japan emerged as the undisputed winner a year later, it took with it the formerly Chinese possessions of Korea and Taiwan. This was the start of the mighty Japanese Empire, an imperial system that would dominate Asia until the middle part of the 20th century. This dominance was spectacularly displayed during the Russo-Japanese war. During a brief but devastating encounter with the Japanese Navy in the Strait of Tsushima, the Russian Baltic fleet was virtually wiped out. No one any longer questioned the ability of the Japanese (Walker B., 2015).

On the other side of the East China Sea, bitter hardship and the humiliation of foreign domination inspired one of the largest uprisings in history, the Chinese Boxer Rebellion. Steeped in mysticism and supported in part by the ruling Qing Dynasty, the Boxer Rebellion was a 
grassroots uprising of hundreds of thousands of Chinese citizens who attempted to uproot the foreigners from their country once and for all. This uprising resulted in the slaughter of untold numbers of Chinese citizens by the foreigners, thus crushing the rebellion fully and completely. The failure of the Boxer Rebellion marked the end of thousands of years of dynastical rule in China. Only afterwards did China take its first true steps into the modern world (Keay, 2011).

As China stumbled into this modern world, bereft of its four thousand year traditions, Japan continued unabated its march toward empire building and the domination of East Asia. During the late 1930's the Japanese war machine poured into China, conquering large swaths of land and committing unspeakable atrocities in the process. This second Sino-Japanese war eventually spilled and merged into the broader Second World War with the surprise attack on Pearl Harbor. For four years the United States battled the Empire until the cities of Nagasaki and Hiroshima were consumed in two incandescent irradiated plumes. Devastated, the Japanese were forced to sign unconditional surrender papers aboard the battleship Missouri. In an amazing echo of history, the Japanese had returned to exactly where they started almost one hundred years earlier: American warships in Tokyo Bay and a treaty which they were forced to sign. The repercussions of Japan's early 20th century aggressions, and the atrocities that accompanied those aggressions, are still felt today: the United States is now firmly embedded in the entire Asian-Pacific region, and Chinese enmity for the Japanese is, in some ways, more powerful today than when the atrocities were first committed (Walker B., 2015).

Despite the end of the war in Asia, the violence was just beginning. The countries of Southeast and East Asia were in a terrible state. Japan was in ruins, and the European colonizers (such as the Dutch, the French, and the British) that still occupied the surrounding Asian countries had been greatly weakened by the war. At that moment in history when European 
colonizers were at their weakest point, a zeitgeist of nationalism seized the imaginations of colonized people all over world who had lived under colonialism for more than a hundred years. Piggybacking these nationalistic independence movements, and sometimes driving them, was Communism. The Cold War had come to Asia, and combined with a desire for independence from colonial powers, war was soon to follow (Osborne, 2013).

These twin movements of nationalism and Communism forever reshaped the face of Asia. Despite trying to stem the tide of history, European colonizers, such as the French and Dutch, eventually lost control of their former colonial possessions after brief and fierce conflicts. The United States did not object to these losses and was, in fact, a proponent of decolonization, having granted its colonial possession, the Philippines, independence in 1948. However, the Communist movements that were encroaching into Asia were viewed as a mortal threat to American security and the established global order. Communist insurrections usually followed the ouster of colonial occupiers, as internal factions within the host country battled over the ideological future of their respective governments. The United States usually backed established post-colonial governments throughout the region in their attempts to defeat Communist forces. Yet by the mid 1950's, Communist forces had made significant inroads into many different countries of the Asia-Pacific region. Vietnam and Korea, hundreds of miles apart, had both been split in two with Communist enclaves in the north of each country, and nationalist governments in the south.

The United States was alarmed at these outcomes and feared that like dominos, the countries of South East Asia would fall to Communism. With Korea and Vietnam fresh on the minds of American strategists and military planners, it was clear that the spread of Communism not only had to be stopped in Europe but in Asia as well. And just as in Europe, the Americans 
felt that the best way to stop the spread of Communism was through a military alliance (Fenton, 2012)

SEATO, or the South East Asian Treaty Organization, was the first Western-backed military alliance that had been established in South East Asia. Like its European counterpart NATO, SEATO was designed from the outset to stop the spread of Communism. Of the eight nations that participated in SEATO, only two were actually in South East Asia. Nevertheless, the pact members were committed to each other's mutual defense in much the same way as were the members of NATO. Yet, in addition to SEATO member states, so called "Protocol States" were included under the pact's defensive umbrella. These protocol states were comprised of the countries that had been French Indochina (excepting North Vietnam). While the organization was reasonably successful during its early years, it fell apart during the Vietnam War. The Americans immediately wanted SEATO to intervene in South Vietnam during the outset of the war to stop North Vietnam. However, despite being a protocol nation and falling under the protection of SEATO, the French-as well as several other members-rejected the idea of giving military support to the Vietnamese. Thus, the United States took unilateral action which ultimately snowballed into the Vietnam War. Shortly thereafter, having failed in its mission and composed of largely disinterested members, SEATO was dissolved. Certainly, any discussion today of a modern alliance in East and South East Asia must include an analysis of the original SEATO defense pact. But we must also remember that SEATO was Southeast Asian in name only; the majority of its members were not even based in the region and, consequently, were not interested in investing military power to protect the region (Fenton, 2012). But there is one organization whose members are in Southeast Asia and whose original mission, like SEATO, was to act as a bulwark against Communism. 
ASEAN, or the Association of South East Asian States, was originally conceived by several Southeast Asian nations to help resist the spread of Communism. Yet, as Asia slowly began to experience a Cold War thaw during the mid-to-late 1970's, ASEAN quickly morphed into an organization focused primarily on the economic growth of its member states. In many ways, ASEAN, and its preoccupation with economic growth, served as a marker for a new era in Asian history (ASEAN, 2016). Colonialism was in the rearview mirror and Communism would continue to fade, becoming increasingly irrelevant.

Economic dynamism was now the name of the game, and many of the countries in the region which had adopted capitalistic models for their economies began to see unprecedented economic prosperity. Japan was the flagship of this movement, and its economy grew at a spellbinding pace. Though it had been left in ruins after war, a generation of Japanese rebuilt their country, creating an "economic miracle" and dominating the Asian markets in the process. The Japanese based their economy on an export model, whereby Japanese goods were exported to more prosperous countries, such as the United States. But the Japanese were not the only players in this new great game; several upstart nations, known as "Asian Tigers", followed closely in Japan's footsteps. These countries also adopted export models and quickly ascended the ladder to economic success. Today, these countries-among them, Taiwan and Singapore-maintain first world economies and are leaders in technology, innovation and production (Kim, 1998). Yet, notwithstanding the outstanding accomplishments of these countries, they are all eclipsed by the unparalleled rise of one nation: China

As the second largest economy in the world, China is the economic behemoth of Asia and, some believe, the driver of the world's economy. But China obviously has not always held this distinction. 40 years ago under the cultish and depraved leadership of Mao Zedong, China 
had become desperately impoverished, with a stagnating economy and a dirt-poor population. However, in 1975 with the death of Mao, a new and rather unlikely leader came to the forefront. Deng Xiaoping was something of a secularist when it came to Communist dogma. Deng believed that China could only survive if it opened up to the West and embraced at least some aspects of the market economy. This led him to take a utilitarian approach to the economy: it did not matter what the label was on the economic system, what matter was that it worked. As he once famously said "it does not matter if a cat is black or white. It only matters if it catches mice." And under Deng's reforms, the Chinese economy would soon catch many "mice." (Osnos, 2015).

The wider the Chinese markets opened, the more the country experienced a meteoric rise. In fact, China became so open at one point that the Communist Party almost lost control. The protests that erupted in China in 1989 had originally started as gatherings to mourn the death of the moderate Communist Party member Hu Yaobang. These tributes, however, soon morphed into full-blown calls for reform and even democracy. Initial government attempts to quell the protests failed, leading to the ultimate decision on the part of the Party to violently suppress the uprising. This action was a turning point in modern Chinese history. Though the protests had been suppressed, the people were obviously unhappy with the state of their country. Thus, the Communist leadership made a sort of grand bargain: they would provide the people with economic growth in exchange for the people letting the party stay in power. And from that time until now, this exchange has worked wonderfully (CFR, 2009).

Since 1978, China has experienced, on average, a ten percent growth in GDP year after year. More than 800 million people have been raised out of poverty and the country's entire infrastructure has been rebuilt in just over 30 years. Based on the same export models that made 
other Asian countries so successful, China has become the so-called factory floor of the world. China is the new economic miracle of Asia, and since admission to the World Trade Organization in 2001, its growth has become even more meteoric (CFR, 2009). From an outside perspective, this rise has been a peaceful one with no more than a few hiccups. But there have been small, troubling, almost imperceptible actions taken by the Chinese government which, combined with their military build-up, presents a disturbing pattern.

The Chinese economy is now undeniably slowing down, and it's something that the government is desperately trying to stop (BBC, 2016). With the lingering effects of the 2008 financial crisis, Chinese manufacturers have seen a slump in global demand. People either aren't buying anymore or are not buying as much. Factories have slowed production, or closed and moved, and exports have fallen correspondingly. Also, China is not the once desperately poor nation of yesteryear. As Chinese labor has become more productive, the cost of doing business in China has risen, which, in turn, has also pushed manufacturing outside of the country (Smith N. , 2016). Confronting this slowdown and drop in demand, the government has used virtually every tool available to them.

Massive stimulus spending and infrastructure projects were initiated by the central as well as local governments (Matthews, 2016). The currency has been purposely devalued in order boost the attractiveness of exports (Smith C. , 2016). Chinese regulators even went so far as to threaten prison for reporters who "spread rumors" about the falling Chinese stock market and went on to blame "foreign forces" for manipulating the market (Yan, 2015). And these problems have not abated. In the steel industry, for example, a business which is largely state-owned, demand has fallen to all-time lows. But apparently, no one told the government. Chinese state owned steel mills keep producing massive amounts of steel, far more than the market can absorb. 
Thus, prices and demand continue to fall while the factories continue to produce. The problem is that the industry employs millions of Chinese workers, and slowing production would cause severe social disruptions. Thus, the steel industry, and the economy as a whole, is stuck in a cycle of over-production and under-demand (BBC, 2016). The Party is having more and more trouble upholding its end of the power-for-prosperity bargain. In what is perhaps not a coincidence, Chinese foreign policy in the South and East China Seas has become more aggressive since the Chinese economy has fallen on hard times.

In just the past few years, China has begun a process of assertively pushing its claims to the South China Sea. At first, it aggressively shadowed the naval, fishing, and oil exploration vessels of neighboring nations and the United States. This, though, soon escalated into more aggressive confrontations and attempts to disrupt the lawful activities of those vessels. In 2012, China cut off access to Scarborough Shoal and did not allow Philippine vessels to enter. Seeking to finally resolve the diplomatic dispute in the South China Sea, the Philippines filed a claim with the Permanent Court of Arbitration in The Hague in 2013 (AMTI, 2015). In the three year span from the filing of that case to the decision, China brazenly defied international norms and law, such as the United Nations Law of the Sea Treaty by constructing over half a dozen artificial islands in disputed waters (CFR, 2016). These sandy monuments are a testament to China's determination to unilaterally lay claim to the South China Sea, and they have greatly alarmed and upset the neighboring countries and opposing claimants. Entreaties have been made by other nations, both inside and outside of the region, as well as organizations such as ASEAN, to diplomatically resolve the crisis through a myriad of forums and summits. But China stands steadfast in defiance, declaring its independence of all international norms and rules, and 
reasserting its supposed unassailable claim to the waters and geographic features of the South China Sea (Phillips, 2016).

Though China has not yet expanded its island reclamation projects or declared a new air defense zone, opposing claimants fear that just such a move is around the corner. Any such provocation would bring us to a unique and dangerous point in history. China has always been a great-or, at least a potentially great-Asian power. Mired in internal chaos and burdened by external threats, China has never commanded the sort of power that regional neighbors such as Japan have. But now after overcoming their Century of Humiliation, civil war, and Communist misrule, an empowered China is transcending its historical limits and is going on the offensive. Few nations resent the rise of China. In fact, China maintains trade relations with almost every nation in the region. But the bold and unprecedented territorial expansion that China is currently pursuing, is very troubling to its neighbors and trading partners in the region today.

Against this new 21st century hostility stands the entrenched older powers such as Japan and the United States, both of which have held economic and military might in the region for well over a century. Both China and the more established powers are now at loggerheads over China's aggression, and the future is uncertain at best. If the past is a prologue, China will almost certainly keep pushing the literal boundaries in the South China Sea, despite the Permanent Court's recent decision in the Philippines vs. China (PCA, 2016). But how will its neighbors respond? Current strategies for curtailing China's aggression have fallen flat, so could a new strategy be around the corner? Might nations opposed to China's expansionism take a page from European history and form a defensive military alliance such as an Asian NATO or a revived SEATO? And if they do, what are the challenges inherent to forming such an organization? In fact, the question of alliance building and balancing against rising powers is discussed at length 
by political scientists. These scholars have long debated the motivations for the aggression of rising powers as well as the responses to such aggression by established or surrounding powers. And perhaps no other theoretical school of thought is more concerned with or has better answers to these questions than the school of Realism.

\section{Theoretical Framework}

Realism is a classic way of viewing the international order and community of states. The tenets of Realism would have been very familiar to ancient scholars and were, in fact, taught by the Greeks. This ancient view of international politics, known as Classical Realism, saw conflict and power struggles in the world as a result of the corrupt nature of man. Yet, despite being the grandfather of Realist thought, Classical Realism is not the only strain of Realist theory. On the contrary, there are many different offshoots on the Realist theoretical tree. Even so, all Realist theories and sub-theories share several core assumptions about the world and the politics within it.

Modern day realism, often identified as Neo or Structural Realism, conceives the world as an anarchical environment where each state seeks to maximize its power and security relative to others. Unlike their Classical forbearers, Structural Realists see the conflicts and power struggles of the world as not rooted in the nature of man, but rather in the structure of the international system. It is the anarchy of this system or structure-the lack of any overarching authority over states-that foments and causes conflict. In this anarchical world, the state alone is the primary actor. The state has no higher power to appeal to, nor a " 911 " to call in case of an emergency. Thus, it must be self-sufficient and rely only on its own abilities. In pursuit of this self-sufficiency, states seek to maximize their power in order to be secure (Mearsheimer, 2001). But how much power is enough? Here, there is a split among Realist theorists. Defensive 
Realists believe that states only seek as much power as is necessary to be secure (Waltz, 1979). Offensive Realists, on the other hand, ridicule this idea. How much power is enough to be secure? States, the Offensive Realists point out, cannot predict which other states will rise to challenge them, and thus cannot accurately gauge how much power they will truly need to be safe. Hence, the only way to be secure is to become a hegemonic nation, building the most powerful state in the region (Mearsheimer, 2001). Potential hegemonic nations are also known as revisionist powers in that they seek to change the established balance of power. Indeed, a potential hegemon must be powerful enough to beat any and all states in its local region, though not necessarily all at once. It is striking to note that this could well describe China. China certainly is, as some have described it, "changing the facts on the ground." (Haddick, 2014) That is to say, through its construction of islands, declaration of air defense zones, aggressive military posture, and massive build-up in military spending and capabilities, China is slowly but surely becoming a regional hegemon. This, of course, is greatly upsetting the existing order and older powers. To be sure, the rise of a potential hegemon is dangerous, but in one particular environment it is especially dangerous.

Realists usually describe the world in terms of power distribution or polarization. In a bipolar world, such as existed in the Cold War, there are two predominant great powers. This global environment is considered by many Realist thinkers to be the most stable and peaceful distribution of power. But a more unstable distribution of power is a multi-polar world. Here, there are multiple great powers, all distrustful of each other and seeking to maximize their own individual security. Multi-polar worlds are more dangerous because the possibility of miscommunication, or the likelihood of an accident, occurring between two or more of the powers increases significantly. Into this mix, a potential hegemon can be very dangerous 
(Mearsheimer, 2001). Although the world has been described as unipolar with the United States as the sole super power (Mowle, 2007), that view seems to be fading into obsolescence (Burrows, 2016). Burdened by financial crisis at home and wars abroad, the United States is not quite as powerful as it once was. Nor are its enemies and rivals as weak as they once were. Thus, the rise of China as a potential hegemon is especially concerning considering that the power arrangement in the world is increasingly multi-polar. But how will the other powers in this multipolar world react to a potential hegemon?

Faced with the prospect of a rising and powerful potential hegemon, states have several options. They can pass the buck to another state, hoping that that state will deal with the hegemon; they can band wagon with the rising hegemon and simply join them; or, they can balance against the rising hegemon by banding together and forming an alliance (Walt, 1987). China, seeking to control both the East and South China Seas, threatens almost every one of its neighbors in the region. Thus, passing the buck would do none of these powers any good as it would not solve their direct individual conflicts with China. Bandwagoning, while initially seeming like an option, is, in fact, highly unlikely. As some Defensive Realists explain, nations almost always choose to balance rising powers rather than acquiesce. In fact, the more aggressive a rising state is and, paradoxically, the more powerful it is, the more likely the other powers will balance against it. This is true even for weaker states facing the hegemon if those states can balance with more powerful states against the hegemon (Walt, 1987). In Asia, we see just such a scenario.

China has proven to be an aggressive and powerful rising hegemon, but it is rising into a world already populated by powerful states. In the East and South China Seas, the theoretical expectation, given what we know, would be for the states surrounding China to balance and ally 
themselves against China. But Realists caution that all alliances are, at best, only temporary marriages, entered into out of convenience and lasting only so long as the threat does (Mearsheimer, 2001). Additionally, some scholars have theorized that balancing is only the initial response to a rising hegemon. Eventually, they argue, if a rising hegemon continues to accumulate ever more power, it will make balancing ineffective and attract to itself all who initially opposed it, causing them to finally bandwagon with the hegemonic state (Fiammenghi, 2011). While this may be true in the long-run, balancing may still be the best choice at this point in the history of the Asian-Pacific region. But how will the global power scales be balanced? Would an Asian-NATO alliance be best way to offset the aggressive, hegemonic-like rise of China, or would an already existing organization accomplish the same thing? Modern scholars are divided over the solutions to the present diplomatic crisis in the South China Sea, and thus, it is best to cover a range of opinions. First, we will look at NATO as a possible balancer to China and how scholars view NATO's role in the Asia-Pacific Region and the conflict that is brewing there. Next, we will review a host of other scholars who believe that ASEAN is the solution for resolving disputes between China and its neighbors. Finally, we will see how, in the absence of ASEAN, many scholars have called for the United States to balance the power scales in Asia.

\section{Literature Review}

When discussing alliances and balancing, it is instructive to first look at current discussions surrounding NATO. Some Regime theorist scholars have described NATO, and alliances in general as promoters of common national values. But other more Realist scholars counter this idea, and believe that NATO's members adhere to a more Realist ideology. Alliance members, they assert, only because it benefits their respective countries. Alliances, they believe, 
are inherently self-centered (Duffield, 1995). Others echo this sentiment by explaining that most NATO members join the alliance simply so they can pass the buck on defense (Thies, 2003). Turning to Asia, and NATO's involvement there (or lack of it), some writers have explained that NATO has remained aloof from Asia because NATO members traditionally viewed the Asian world as backwards (Hemmer, 2002). Others explain that the absence of NATO from Asia is due to the traditionally low threat environment in Asia and the prioritization of Europe (Kai, 2012). On the other hand, some have reported that NATO is now seeking to become embedded in the region (Bagbaslioglu, 2014). But this idea is largely a minority view and is countered by experts who argues that NATO does not wish to expand outside of Europe (Fallon, 2013). In the absence of NATO filling the alliance gap in Asia, and balancing against China, some have looked to regional multilateral economic cooperation organizations to do so.

\section{The ASEAN View}

Perhaps the most prominent of the multilateral, Asian-based organizations, is the Association of South East Asian States (ASEAN). Although ASEAN is primarily an organization with economic centered goals, it does have a history of resolving diplomatic disputes in the region. This is a tradition that some scholars hope to build upon by promoting ASEAN as the primary arbiter for the South China Sea, and the solution to ongoing diplomatic disputes.

ASEAN, as some Liberal theoretical scholars point out, has an unparalleled history of solving diplomatic disputes in the Southeast Asian region. ASEAN, in and of itself, represents a tremendous diplomatic accomplishment. ASEAN, through its legal mechanisms and various treaties, has linked together the entire Southeast Asian region through economic integration. With these accomplishments in mind, many argue that ASEAN is still the best way to resolve 
current diplomatic disputes in the South China Sea (Oegroseno, 2013). This view is backed up by other scholars who remind readers that ASEAN has not only been involved in resolving disagreements among its own members, but has, in fact, been a key arbiter in the South China Sea dispute for several decades (Thayer, 2013). Furthermore, during that time, ASEAN ensured that a peaceful status quo was maintained in the South China Sea (Weissman, 2010). In an effort to promote continued cooperation in the region, some scholars suggest that more meaningful ASEAN-Chinese relations should be pursued through joint cooperation in energy transportation and exploration (Hong, 2010). Others seek to strengthen the ASEAN-Chinese relationship through already existing Chinese bi-lateral ties with various ASEAN member countries (Limsira, 2014). Still more believe that common environmental goals would do much to deepen the ASEAN-Chinese working relationship (Borchers, 2014). But just as many scholars are optimistic about ASEAN's role in solving regional disputes, many others, are very skeptical.

Returning to Realist thought, some scholars note that, while ASEAN solved the VietnamCambodia crisis during the 1970's, today, ASEAN's regional forums and dialogues have done little to promote collective security (Evans, 2001). This analysis is supported by other authors who explain that, in the shadow of a rising China, ASEAN is being pulled at the seams. Each member is being forced to decide whether or not it is on China's side (Seng, 2015). This pessimistic view is echoed by many other authors. ASEAN, as well as the Asia-Pacific Economic Cooperation forum (APEC), has been essentially unwilling, when asked by the United States, to confront the growing security challenges of the region (Schmitt, 2006). This, despite the United States' attempt to elevate ASEAN as a key diplomatic forum for the ongoing South China Sea negotiations (Simon, 2016). In the absence of a regional organization taking charge of security matters, some have suggested a "concert of powers" to address the security concerns of 
Asia. (Capie, 2002). But in light of ASEAN's failure to resolve the crisis and provide solutions, others have promoted the idea that regionalism and cooperation in Asia are not at all realistic (Nair, 2008). This is due, some argue, to the fact that China continually obstructs multilateralism and regional dialogue (Rozman, 2011). A growing chorus of scholars believe that, not only is ASEAN incapable of solving the present regional dispute, but is, in fact, being torn apart by it.

Many writers who are more aligned with a Realist theoretical perspective believe that the diplomatic disputes of the South China Sea, as well as China's aggressive actions there, are pulling at the seams of ASEAN and straining the internal relations of its member states. ASEAN, as one scholar has noted, initially sought to develop close ties to both China and the United States in order to benefit the organization. Unfortunately, the power play between China and the United States, and the dispute in the South China Sea, has driven member states to focus more on national priorities rather than multilateralism and the goals of ASEAN (Jagtiani, 2013). Others single out China's aggression, in particular, as a serious threat to the health and stability of ASEAN (Thayer, 2016b). In this tempestuous environment, some question whether ASEAN will be able to cope with the changing geopolitical environment (Beeson, 2016). Others simply state that in light of China's rise and the United States' strategic focus on the Asian-Pacific region, efforts to promote multilateralism will ultimately fail (Dalpino, 2013).

As we have seen from previous sections, ASEAN seems increasingly unwilling to confront China over illegal territorial acquisitions and its aggressive actions in the South China Sea. This is a fact which has not escaped current scholars, whose tide of opinion seems to have turned in favor of an increasingly pessimistic view of ASEAN's future role in the ongoing disputes. In the vacuum left by ASEAN, a growing body of experts are looking to the United States to confront China. However, not everyone agrees on how, exactly, this is to be done. 


\section{De-emphasizing the United States}

Some put forth the idea that the United States should focus on more regional ties and downplay its bilateral security agreements with nations such as Japan. Containment should not be the objective. Instead, the US should take part in talks such as the East Asia Summit (EAS) and the Asian Pacific Community (APC). And while not advocating ASEAN and APEC, these thinkers still see multilateralism, with a de-emphasis on China, as the key (TOW, 2009). Others take a similar stance. The United States' bilateral partners, they assert, should have more diplomatic autonomy and not be constrained by the United States. Thus, any alliance with the US should be a loose one (Koga, 2011). But many other scholars are totally opposed to this school of thought. They argue for more collective security, especially in light of the rise of China (Rolfe, 2008). Some authors go so far as to label China a hegemonic power. Also, perhaps predictably, these same writers emphasize the critical importance of the United States' bilateral security agreements in the region (Navarro, 2015). Others, nevertheless, see the United States' bilateral agreements with regional individual nations as fomenting a security dilemma. They theorize that an increasing military presence will spur nations such as China to, in turn, adopt more aggressive postures and accumulate more weapons (Park, 2011). But other authors argue that it is the other way around; that it is China that is creating an arms race and the resulting panic. Bilateral and multilateral security agreements, for example, have increased as a response to China and its actions (Bisley, 2012). This is demonstrated through a new bilateral security agreement between Japan and Australia, one of many new security arrangements spurred by China's aggressive actions (Weeks, 2011). Finally, some scholars come close to advocating for a regional defense pact by arguing for the strengthening of the hub and spoke system of alliances. In this model, the United States is the hub and each of its bilateral defense agreements is a spoke. It is argued that 
the spokes need to become a web in order to strengthen the existing defense arrangement. Like an alliance, each member would be committed to the other (Blair, 2001).

\section{Emphasizing the United States}

This strengthening of alliances is seen by many scholars as an attempt by the United States to contain the rising China. Saying just that, one author, who adopts a Realist theoretical outlook, makes the case that the United States is pursuing an obvious containment policy through its strengthening of ties with traditional Asian-Pacific allies while forging new bonds in the region and attempting to limit the economic influence of China (Wong, 2014). Others have come to much the same conclusion, stating that the United States' new "Pivot to Asia" policy is a tacit attempt to preserve American hegemony. However, the strengthening of ties to traditional allies in the region could precipitate greater military competition between the US and China (Lofflmann, 2016). It has also been noted by some Realists that in the process of this rebalancing to Asia, NATO will likely become more and more irrelevant as interests diverge (Maher, 2016). In light of the decline of NATO, Japan, in particular, is seen as a key US regional ally. The United States and Japan are moving closer together as allies, just as China has strengthened ties to North Korea (Goo, 2014). But some Realist scholars are bullish on NATO, predicting that its ties to Japan will become stronger even though Asia is outside of NATO's scope and Japan is constitutionally limited to its immediate region in terms of military projection (Scott, 2016). Using Power Transition theory, Kelly predicts that if the United States, along with its allies, were to balance the rise of China, it would reap enormous benefits from such a strategy as opposed to its more recent record of intervention (Kelly R., 2015). Other scholars argue for a more veiled approach to containment, and thus call for a soft balancing whereby the US strengthens its allies (Burgess, 2016). But this conservative strategy is not shared by everyone. One author takes an 
especially hard tone, condemning the United States' 30-year economic engagement with China as a failed policy, and calling on the United States to greatly expand its naval presence in Asia as well as limiting trade with China (Friedberg, 2012). Not all scholars believe in outright containment, however. Tellis uses contemporary growth theory to emphasize that economic interdependence makes traditional containment impossible (Tellis, 2013).

On the flip side of the coin, several recent academics and experts are noting the closer ties that China has with Russia and the possibility that China could be forming its own alliances. Some focus on China's increasingly close relationships to Iran and Pakistan, relationships which strengthen its position in broader Asia and the Indian Ocean (Khan, 2014). Others show that although Russia and China are pulled in separate directions at times, they still maintain a strong relationship (Russett, 1998). A relationship which is being strengthened by nuclear proliferation in North Korea and the United States' positioning of anti-ballistic missile technology in the South (Bin, 2016).

It seems that the vast majority of scholars have passed over the concept of an AsianPacific NATO-type alliance as a means to balance the rise of China. Some focus on regional solutions from organizations such as ASEAN. But, despite its past successes, ASEAN seems increasingly unable or unwilling to confront China or effectively resolve the burgeoning crisis. This is a reality that is increasingly reflected in the literature. Scholars seem to be pessimistic that any ASEAN led initiative will solve the crisis. With a dearth of leadership from ASEAN, others are looking to the United States to serve as the balancing agent. Within this camp, some advocate a cautious approach. They call for a strategy which would take great pains to avoid provoking China in any way or upsetting the current status quo. Others favor a more aggressive approach and advocate a strengthening of US bilateral alliances. But few if any promote a 
NATO-type organization as the solution to the Asian-Pacific region's problems. This paper will attempt the fill that gap in the literature. We will delve into the various problems that the founders of a hypothetical Asian-Pacific NATO would confront in building the new organization. Yet, before we examine the specific challenges to forming an Asian-Pacific NATO, we will first lay out a road map for the proceeding discussion.

\section{Methodology}

To start, we will define some of our terms and concepts. "Asian-Pacific NATO" or "Asian-Pacific alliance" shall refer mainly to potential member nations, excluding China, that ring the East and South China Seas. These could include Vietnam, the Philippines, Japan, Taiwan, South Korea, Malaysia, and Indonesia. Even countries on the periphery of that region, such as Australia and India, could be included due to their interaction with the regional and territorial conflicts with China. Without a doubt, the United States, which was central to the original European NATO would, likewise, be a central player of any Asian-Pacific NATO. Of course, this is not to say that all these nations would or could make up an Asian-Pacific NATO. Some may be much more inclined to join than others. But considering that China has conflicts with almost every nation in the region, it is not outside the realm of possibility that all could join together. For our purposes, "alliance" will refer to a military alliance similar to NATO. While NATO's scope and mission has expanded somewhat in recent years, this paper will model the hypothetical Asian-Pacific NATO after the earliest incarnation of NATO. The original mission of NATO was to confront and defend against the Soviet Union, and best fits the mission of our Asian-Pacific NATO, namely to confront China. Like the original European NATO, each member of an Asian-Pacific NATO would be treaty-bound to provide aid to any other member whose territory is attacked or invaded. Also, all members' military forces would be standardized 
in order to forge a common fighting force in much the same way that NATO operates. All data used within this thesis will be draw from historical sources and books, as well as contemporary news articles.

The theoretical bedrock of this paper will rest on the foundation of Structural Realism. As discussed above, Structural Realism perceives the world as an anarchic environment where each state is distrustful of its neighbors. In this environment, each state seeks to expand its power in an attempt to balance against potentially hostile neighbors. As we have seen, states can cooperate with each other by forming military alliances in order to balance against larger more powerful states. The purpose of an Asian-Pacific NATO would be to balance against the rise of China. Balancing is a theoretical concern of Realists, some of whom advocate alliances in order to achieve balance against a rising hegemon. Thus, the basis for an Asian-Pacific NATO is found, first and foremost, in Structural Realist Theory. Realists ground this state-to-state cooperation by reminding us that alliances are only ever "temporary marriages of convenience." Thus, while military alliances require and promote cooperation between nations, this cooperation is in the best interest of the state.

The methodology of this thesis will utilize a comparison/contrast method in order to better understand the challenges facing a hypothetical Asian-Pacific NATO. The thesis will compare and contrast the original European NATO with our 21st century hypothetical AsianPacific NATO. Looking back in time to the original European NATO, we will briefly examine some of the various challenges that faced the planners and commanders of that organization. Then, we will look at the potential challenges that could be faced by an Asian-Pacific NATO organization. How did the original NATO confront and solve the challenges which it faced? Are there similarities in the types of challenges both organizations faced and could face? Comparing 
and contrasting both of the alliances will give us insight into what kind of challenges a realworld Asian-Pacific NATO might face and how it could solve them. However, besides simply comparing challenges that both have faced, we will draw out an overall pattern or similarity that makes sense of both alliances' challenges and solutions. This synthesis will be the conclusion of our paper.

A comparison/contrast paper has many inherent strengths. For one, it can make certain qualities visible that are common to both alliances which would be otherwise invisible. Also, a clearer picture of one alliance can be obtained by comparing it with the other. However there are also several distinct disadvantages to a comparison/contrast method. First, the two units being compared may not be truly equivalent. The original NATO was located in Europe while an Asian-Pacific NATO would be located within the Asia-Pacific region. While both organizations are defense pacts, the differences between regions may make any comparison difficult. We are also constrained by a limited number of cases. While there have been other military defense alliances such as SEATO and the Central Treaty Organization (CENTO), the only surviving alliance today, and the only one being used for this paper, is NATO. Thus, since our cases are limited to two, comparing and contrasting our hypothetical Asian-Pacific NATO with the original NATO limits the conclusions that we can draw. Finally, we must be aware of Galton's Problem. Simply put, it may be that the two organizations are not at all separate, but are, in fact, constituent parts of a whole. It may be, for instance, that both of the alliances we are evaluating are nothing more than tools or extensions of the United States government. The United States, for example, already plays an outsized role in the original NATO and would, undoubtedly, play a large role in an Asian-Pacific NATO. Thus, we may be comparing two things that are not separate at all. Keeping these limitations in mind, we still believe that comparison contrast is an 
appropriate and useful method for this thesis. Despite its flaws, comparison/contrast provides us with the ability to draw new conclusions from separate cases. Or, in this case, comparison/contrast allows us to speculate and draw conclusions about a non-existent alliance by comparing it to one which already exists.

The remaining portion of this paper will be devoted to the examination of several of the potential challenges that would need to be remedied before any Asian-Pacific NATO alliance could ever be formed. Following the examination of challenges we will then look at potential solutions to those challenges. First, before we look at solutions for our future Asian-Pacific NATO, we will return to the original European NATO, to see how that alliance solved the challenges with which it was confronted. Then we will see how the potential challenges facing an Asian-Pacific NATO could be solved. Following this section, we will analyze both alliances in order to examine the similarities and differences while offering several policy recommendations. Finally we will conclude our paper by reviewing what we have learned and noting any limitations to our study. Hopefully, this study will add to the admittedly small but, nevertheless, vital discussion of the possibility of creating a military alliance in East and Southeast Asia. 


\section{CHAPTER II: THE CHALLENGES}

In the following chapter we will examine several common challenges that both the original NATO faced and our hypothetical Asian-Pacific NATO may face. Both faced and face the challenge of justifying their very existence. In other words, why were and are they needed? Secondly, the original NATO was faced with the difficult but necessary challenge of admitting a very controversial member to the defense pact. Likewise, an Asian-Pacific NATO would be faced with necessity of including a certain member who would be very controversial to the region. Third, alliances can be expensive, and figuring out how to pay for them is an ever-present challenge. Fourth, the original NATO was faced with several territorial challenges. However, nothing faced by NATO can compare to the unprecedented and complicated territorial disputes with which an Asian-Pacific NATO would have to contend. Finally, the original NATO was faced with the prospect of blowback, or consequences for its actions. Similarly, an Asian-Pacific NATO would have to tread a fine line to avoid significant blowback from its actions.

\section{Old NATO, Old Challenges}

The prospect of building a new alliance is a daunting one, though it has been done before. Yet just like today, the planners and commanders of the original European NATO faced many different challenges. And in order to compare and contrast the new with the old, we need to go briefly back in time and touch on the myriad of challenges that the original NATO faced.

One of the most fundamental challenges faced by the original NATO was justifying the very reason for its existence. Prior to the formation of the North Atlantic Treaty Organization, the Treaty of Brussels was a defensive alliance which had been signed by several Western European nations. Similar to NATO, the Treaty of Brussels was a defense pact which guaranteed that the respective members of the pact would come to each other's mutual aid and defense 
should a war break out. Thus, in light of that treaty, it was more than fair to question the very need for the subsequent formation of NATO. However, once NATO was formed, it faced another, seemingly greater, problem. NATO needed more soldiers. Yet the only way to obtain them was to add a new-and very controversial-member. West Germany had the troops that NATO desperately needed if it was to secure the continent against Soviet incursions. But many members, and even the Soviet Union, objected to Germany's inclusion. If it included the German forces, NATO risked alienating members and adversaries alike (Gaddis, 1998).

Another challenge that NATO members faced during the Cold War was paying for the astronomical cost of maintaining their respective militaries. Each member was, and is, required to spend a minimum amount of GDP on defense. However, these cost were often heavy and this proved to be a perennial challenge for the military alliance. Not only did alliance members have to maintain their militaries, they had to continually improve them to stay ahead of Soviet advances. Throughout the long standoff between the Soviet Union and NATO, there also arose several territorial challenges that had to be resolved peacefully. In fact, during the Cuban Missile Crisis, the territorial integrity and security of both NATO and the Soviet Union were challenged. Finally, NATO had to face the challenge of "blowback." Some of the actions that the European NATO defense pact took were controversial, and there was always the possibility that the Soviet Union would respond dangerously to the strategies or programs enacted by the alliance. One of the primary concerns of the defense pact was to minimize these negative reactions and responses and thus minimize the probability of war (Gaddis, 1998).

These challenges, while significant, were all solved by the original European NATO. And while an Asian-Pacific NATO has not yet been formed, it would undoubtedly face many 
challenges of its own. Some of these new challenges are similar to the original NATO's challenges while others are entirely new.

\section{Challenges of a 21st Century Asian Pacific NATO}

NATO was faced with many challenges, however, they are not at all dissimilar from those that an Asian-Pacific NATO could face. Both have to justify their existence, and include controversial members. Furthermore, both have to contend with large defense spending costs. Also, both organizations faced the very real prospect and consequences of blowback. However, when looking to territorial disputes, it is clear that the original NATO never faced the kind of complex territorial disputes that an Asian-Pacific NATO would face.

The assumptions behind these hypothetical challenges for a 21st Century Asian-Pacific NATO are firmly rooted in Structural Realist theory. For one, the examination of the need for an alliance is rooted in the Structural Realist assumption that, in the face of a rising power, alliances will form to balance that power. Secondly, the study of the constraints which could prevent Japan from joining an Asian-Pacific alliance reflects the Structural Realist idea that nations are suspicious of their neighbors. Given recent history, Japan's neighbors are especially suspicious of that nation. Thirdly, in the world of a Structural Realist, nations continually attempt to increase their power relative to other states. However, how will the nations of an Asian-NATO, and especially the United States, afford this additional security? Moving to the theoretical justification for our fourth hypothetical challenge, we recognize the Realist assumption that nations-being suspicious of their neighbors-will jealously guard their territory. But in the complex environment of the South China Sea, what territory would an Asian-Pacific NATO actually defend? Finally, the risk of Blow Back, or a disproportionate response by the Chinese to the creation of an Asian-Pacific NATO, reflects the Structural Realist fear of security dilemmas. 
Security dilemmas occur when the actions by one state, or group of states, to enhance security, precipitates a similar response by opposing states. In the case of an Asian-Pacific alliance, it may be that the creation of such an organization would spur the Chinese to create a similar organization or take other steps to further enhance their security. With our challenges anchored in Structural Realist theory, we can now move on to examining the challenges themselves.

\section{Challenge \#1: Hub and Spoke Sufficiency}

One of the first questions that should be asked when constructing an Asian-Pacific alliance, is whether or not it is even needed. In fact, the United States already has an impressive collection of alliances in the Asia-Pacific region. But, it was not always this way. In the formative years of the United States, the founding fathers continuously warned against so-called entangling alliances. In his inaugural address, Thomas Jefferson declared that the United States ought to have "peace, commerce, and honest friendship with all nations, entangling alliances with none." Washington had preceded this credo with his admonition against "permanent alliances." This diplomatic philosophy was adhered to by the United States until the end of the Second World War when Soviet expansionism prompted the creation of NATO. And while NATO may have arguably been the first major "entangling alliance" the United States entered into, it was certainly not to be the last.

Today, the United States maintains more defense-related treaty obligations than any other country in the world. By some estimates, depending on which treaties and obligations are counted, the United States is bound to protect more than a quarter of humanity. That's about 69 nations in all, representing more than 75 percent of all global economic output (Taylor, 2015a). In fact, in recent years, the commitments of the United States have only continued to expand as 
new nations have joined NATO (Taylor, 2015b). This tremendous commitment is the aggregate of a myriad of defense pacts and bilateral defense agreements. Almost without a doubt, the most important of these commitments to date is NATO. Other treaties include the Rio Pact and ANZUS or the Australia, New Zealand, United States, Security Treaty. Yet in East and Southeast Asia, with the exception of ANZUS, the United States does not participate in any overarching security organization. Instead, the United States maintains a "hub and spoke" system of bilateral defense treaties with many nations in the region. In this hub and spoke system, the United States is the "hub" while each country that it maintains a defense treaty with is a "spoke." Thus, if one nation is attacked (Japan, for example), there would be no regional response of treaty-bound nations to respond such to such an event, as is true in Europe. Instead, it would most likely be the United States alone that would come to its aid. Thus, in the wake of the failure of SEATO, the hub and spoke system has functioned as a sort of alliance system in Asia without any of the attendant benefits or liabilities of such an alliance. In East and Southeast Asia, there are three main or major countries, or "spokes", with which the United States maintains official defense pacts: the Philippines, Japan, and South Korea (Navarro, 2015).

In 1951 the United States signed a mutual defense treaty with the Philippines whereby each signatory promised to aid the other in a time of war. The Philippines proved to be a vital ally throughout the Cold War, as it provided key military bases for US forces. But following the end of the half century-long US-Soviet standoff in 1991, the Philippines decided to eject all American military forces from the Philippines. The massive and strategic Subic Bay naval base, where US naval ships were repaired and replenished, was ultimately closed as well as Clark Air Force Base (Francia, 2013). At the time, this may have seemed an inconsequential decision for the Philippines, but almost immediately, the Chinese began to slowly encroach on Philippine 
territory (Baltimore Sun, 1995). Over the coming two decades the Philippines found itself in an increasingly dangerous diplomatic dispute with China. The Chinese effectively seized Scarborough Shoal from the Philippines in 2012 which, among other actions, led to the Philippines' filing a case with the Permanent Court (AMTI, 2015). Interestingly, although falling under Philippine sovereignty according to international law, and despite still maintaining a defense treaty with the United States, the United States, in fact, did nothing to stop the Chinese from seizing the shoal. This move has been criticized by some; however the United States may have simply been caught off guard (Chang, 2013). In any case, reports indicate that the United States has been in contact with China, warning them to not construct any artificial islands on the shoal (McDevitt, 2016). With the United States' and Philippine's defense treaty on shaky ground, and perhaps with the intention to send a message to China, the two nations reaffirmed their bilateral defense treaty in 2014 (Heydarian, 2016). This move is expected to strengthen ties between the two countries and will once again allow the United States limited access to Philippines bases and thus ensure an American presence in the region. But with these renewed privileges, the United States is also inheriting a Philippine conflict. With Scarborough Shoal in the hands of the Chinese, the United States may be called upon to intervene in any escalation of Chinese-Philippine relations. Worse yet, the Philippines could do little else to aid the United States in such a conflict outside of providing bases. The Philippines hardy has a navy to speak of and is armed with an underfunded and poorly trained army (Parameswaran, 2015). The treaty between the United States and the Philippines may be bilateral, but for all intents and purposes, it is one way. Yet, the Philippines is only one of many regional states to which the US is linked by treaty. 
Japan is one of the biggest, and in many ways, most important US military partners in the Asia-Pacific region. With over 109 bases and 50,000 troops stationed in the country, the US maintains a significant presence in that country. Japan also hosts several important naval bases outside of the US, making it a strategically vital ally. But the path to vital ally was not an easy one for Japan. After the bombing of Pearl Harbor, the United States waged a bitter war with the Empire of Japan until Japanese leadership finally capitulated. But, just as in Europe, the end of the Second World War ushered in the beginning of the Cold War. Unwilling to let the Soviets obtain a foothold in Japan or in the rest of Asia, the United States established a massive military presence on the islands of Japan. During the Korean and Vietnam Wars and all throughout the Cold War Era, Japan has been the mainstay ally of the United States in Asia (Dian, 2014). However, this special relationship has not come without bumps in the road.

From time to time, pacifistic elements of Japanese society have demanded the ouster of American forces from Japan. Sometimes, these demands are based on the disruptions to local communities caused by US military bases, and other times the demands come as a response to crimes committed by US personnel. Even the alleged presence of nuclear weapons has helped to anti-US sentiment from time to time. During the 2009 Japanese election cycle and the resulting electoral victory of the Democratic Party of Japan, it seemed that US-Japanese relations were going to take a turn for the worse. DPJ wanted to distance itself from the United States while moving closer to China. However, the implementation of DPJ's vision was flawed and shortlived. Following aggressive Chinese actions in the South China Sea, the opposing Liberal Democratic Party, or LDP, which has been the most powerful party during most of Japan's democratic history, defeated the DPJ and elected Shinzo Abe as Prime Minister of Japan (Dian, 2014). 
Abe has taken a bold and more nationalistic approach to governing Japan. Faced with a flagging economy and an aggressive Chinese neighbor, Japan has drifted from its pacifist roots and restrained foreign policy. In addition, Abe has made it clear that the Japanese-US relationship is vital to Japanese security in the 21 st century. In fact, Abe has increased military spending and has even bent the rules of Japan's pacifistic constitution to ensure that Japanese troops could assist allies outside of Japan. Unlike their Philippine counterparts, the Japanese have a robust economy and a relatively powerful military, considering the restrictions placed on it. Abe's more strident, militaristic style is largely a response to increasingly aggressive actions by Chinese military and naval forces in and around disputed islands in the East China Sea (Hughes, 2015). Thus, like the Philippines, volatile times have pushed the United States and Japan closer together, strengthening their special relationship and banishing any thought of separation.

Finally, the last of the United States' three main bilateral allies in the region is South Korea. With the end of the Korean War, and the permanent separation of North and South Korea, the United States signed a mutual defense pact with South Korea. As with the other defense pacts signed by the United States, the Korean defense pact provided the United States yet another strategic outpost in Asia. However, unlike the Philippines or Japan, South Korea has technically been in a state of war for more than 60 years. Miles away from the capital city of Seoul lies the demilitarized border with North Korea. North Korea has proved to be a dangerous neighbor, and one against which the South Koreans must constantly defend themselves. Despite the end of hostilities for more than half a century, the two countries have almost gone to war multiple times within the last several years. It is here, in this nation, that the United States' defense pact may end up meaning more than almost any other pact in the region. With more than 30,000 US 
soldiers ready to defend South Korea, the United States could very well be pulled into a war by the unpredictable actions of North Korea. Yet, despite being threatened by North Korea, South Korea has not yet had to face down an aggressive China. Unlike Japan or the Philippines, South Korea has only very minor territorial disputes with China, none of which have escalated in any appreciable way. However, North Korea has historically been influenced by China, one of the few countries willing to trade with them. And, depending on the continuing depth of this relationship between the two nominally Communist powers, South Korea may or may not find itself at odds with China. While the Philippines, Japan, and South Korea represent the most sizable defensive partners in the region, they are not the only spokes connected to the hub of the United States (Oberdorfer, 2013).

The Republic of China, now more commonly known as Taiwan, once maintained an official defense pact with the United States like Japan and South Korea. However, during the 1970's the United States normalized relations with the Communist mainland China, and in a diplomatic move, ended the defense treaty with Taiwan. This does not mean though that the United States does not maintain a military relationship with the island nation, nor does it mean that the US would not defend it. In 1996, following threatening Chinese actions directed against Taiwan, the United States sent a resoundingly clear message that it would protect Taiwanese sovereignty, sending several aircraft carrier groups to prowl the Taiwan Strait in a clear show of force. Continuing this commitment, the United States recently approved an almost two billion dollar arms sale-over the objections of the Chinese-to the military of Taiwan (Bush, 2015). Australia, too, is another spoke in the United States Asian-Pacific hub and has been since the enactment of the ANZUS treaty (Donnini, 1991). In fact, the spoke system maintained by the United States only seems to be adding more spokes. Vietnam, while not a country protected by 
the United States, now enjoys US arms deals like its neighbors, thanks to the rescinding of a thirty-plus year arms embargo (Harris, 2016). Thus, while not all spokes are equal, the combination of them represents a significant de facto military alliance. But is it as effective as an actual military alliance? Does it fill the role of an Asian-Pacific NATO?

As we have seen, many experts and scholars suggest that the most effective way for the United States to deal with China is to continue to strengthen and support its allies in the AsiaPacific region. Indeed, China's actions have driven America's allies and even former enemies into America's arms. China is quickly becoming a threat similar to what the Soviet Union was during the Cold War. An external threat, a glue that holds together allies and drives nations into the arms of the United States. But is this hub and spoke system enough? Returning to Realist theory and our primary concern, is the hub and spoke system enough to balance the rise of China, or is a more traditional, NATO-type alliance needed? Overcoming the argument for the sufficiency of the Hub and Spoke system, and effectively arguing its insufficiency, is only one of the many challenges faced by those who would create an Asian NATO.

\section{Challenge \#2: The Tale of Two Yurei, or the Tale of Two Ghosts}

If an Asian alliance were to ever become a reality, one nation-outside of the United States-would be vital to its success, and that nation is Japan. However, there are several serious barriers to this admission. As a populous, economically strong and technologically advanced nation, Japan is certainly the strongest of the "spokes" and would be the backbone of any potential Asian-Pacific NATO. Without Japan, any serious balancing attempt against China, would not be feasible. Japan has the third largest nominal GDP in the world, producing over four trillion dollars in goods and services. Japan is also a global leader in technology and advanced manufacturing, as well as home to some of the most prosperous companies on the planet. 
Mitsubishi, Toyota, and Toshiba are only a few of the world leaders in manufacturing and technology (CIA, 2016). But despite all of its tremendous success, Japan is haunted by two Yurei, two ghosts from the past that could prevent it from ever taking part in an Asian-Pacific alliance. The first of these specters is Japan's military, or rather the constitutional limits put on it. The second, is the persistent legacy of Japan's past war crimes.

Japan's power not only resides in its robust economy but in its powerful military as well. Japan ranks eighth globally in military spending, a sum which has provided the state with the tenth most powerful military in the world (Macias, 2014). This typically conservative, postWorld War II force, has begun in recent years to stretch the limits of its pacifistic constitution. For example, prohibitions on exports were recently lifted, allowing the once-isolated Japanese military industrial complex to begin to spread its wings. Pushing back against the rise of China and perhaps seeking to play a larger role in the region, the Japanese are beginning to sell weapons and military systems to their neighbors, bolstering regional defense and, in the process, strengthening their bilateral ties.

Japanese patrol boats have been sold to the Philippines and Vietnam, while Japanese submarines have been advertised to both India and Australia (Keck, 2015). And while these sales are relatively small compared to the global defense market, they are baby steps that may precede a large scale expansion in both Japan's military manufacturing and defense posture. Japan could conceivably become a sort of 21 st century "arsenal of democracy;" its advanced military industries arming the potential alliance. And its military force could rival or surpass almost any in the world. But there are severe limitations to fulfilling this role.

Shigeru Yoshida was the first prime minister of post-war Japan. Japan had been completely devastated following the war, leaving its cities, industries and economy in ruins. 
Faced with starvation, economic depression, and national desperation, Yoshida made the controversial decision to ignore rebuilding the Japanese military and focus instead solely on the Japanese economy. Japan's defense, he argued, would be provided for entirely by the United States, leaving the Japanese people to reconstruct their country. This so-called "Yoshida Doctrine" has been the guiding principle for much of Japan's post-war history. However, it wasn't as if the Japanese had much of a choice in the first case.

The United States, as it did in Europe under the Marshall Plan, did much to help rebuild Japan. They did not want the Japanese, driven by hunger, desperation or humiliation, to join with the Communists and become remilitarized. Thus, the allies, under the leadership of General MacArthur, pursued a policy of rebuilding the Japanese economy. But it was not just the physical infrastructure that was to be rebuilt. Under allied guidance, the Japanese imperial government was abolished and democracy put in its place. A constitution was written that gave women the right to vote and guaranteed freedom of speech among other rights. But along with the articles that granted liberties were sections which placed onerous restrictions on Japan's military and defense strategies.

Article Nine of the Japanese Constitution strictly forbids the development of any armed forces with "war potential." This somewhat enigmatic phrase has long since been interpreted to mean offensive military capabilities. But even this definition is somewhat confusing. Generally, weapons singled out in interpretations include, first and foremost, nuclear weapons as well as those systems that allow "force projection" such as aircraft carriers and bombers. Thus, for more than seventy years, the Japanese government has maintained a limited "defense force" which for all intents and purposes is a military. This compromised force, along with the focus on the 
Yoshida Doctrine, has allowed Japan to experience economic growth and prosperity. But the times have certainly changed since Yoshida first came to power (Port, 2009).

Today, Shinzo Abe, not Yoshida, is prime minster of Japan and, unlike his predecessor, Abe and his fellow citizens face entirely new challenges. The Senkaku or Diaoyudao Islands, depending on which country is asked, are a fiercely contested set of Islands administered by Japan. China, of course, claims that historically the islands are Chinese. And, as in the South China Sea, it has taken aggressive actions to assert that right. Chinese fishing boats and naval vessels have approached the islands and harassed the Japanese Coast Guard. Chinese military aircraft have buzzed the islands multiple times prompting the Japanese to scramble fighter aircraft and remain on high alert. Japan, like its neighbors, is faced not just with a single diplomatic dispute, but with a China that is becoming increasingly hostile (CFR, 2016).

To meet this gathering storm of Chinese aggression, Prime Minister Abe and the conservatives he leads have had to become somewhat creative in their interpretations of the traditionally pacifistic Japanese constitution. Japan, as has been shown, has traditionally been limited to defensive actions and technology. However, under Abe, a so-called "Dynamic" defense posture has been adopted (Hughes, 2015). Having always been prohibited from exporting weapons, Japanese defense contractors, such as Mitsubishi Heavy Industries, produced only limited numbers of weapons for the exclusive use of the Japanese military. Now, however, the ban has been lifted, and Japanese companies are looking for new customers. Though they were recently outflanked by a French defense manufacturer in a deal to supply advanced diesel submarines to Australia, many have attributed the loss simply to the total lack of experience Japanese defense companies have in selling abroad. Despite this setback, Japanese weapon systems will almost certainly begin to have a significant impact on the region (Kelly T., 2016). 
Another significant shift in the Abe administration's interpretation of the constitution is its new doctrine of collective defense. Traditionally, the Japanese military was reserved strictly for the defense of Japan. No other country or military could receive aid from the Japanese due to constitutional restrictions. However, the Abe administration has argued that coming to the aid of allies is in the best interests of Japanese defense. Armed with this new interpretation, Japanese soldiers could find themselves fighting on the Korean border or in the Pacific with the American Navy. Certainly then, this controversial reinterpretation has the potential to radically expand the role of the Japanese military (Mie, 2016). But it is not without controversy.

Many in Japan feel that Abe's actions are blatantly unconstitutional. And the pacifistic Yoshida tradition still runs strong in Japanese politics. Getting Japan to fully abandon the tenets of Article Nine and rearm would be a historic if not difficult accomplishment, but one that is almost certainly necessary in order to form an effective defense pact. Moving to the second of the two ghosts which still haunt Japan to this day is the lasting legacy of Japanese war crimes committed during World War II.

During the war, Japanese military commanders and soldiers committed some of the most horrific war crimes of the entire war. In China, the invading Japanese slaughtered hundreds of thousands of civilians by shooting, hanging and even burying them alive. The Rape of Nanking, perhaps the most notorious incident of Japanese genocide against civilians, resulted in the deaths of 20,000 to 300,000 Chinese civilians, though the numbers are disputed. Thousands of women from China, Korea, and the Philippines were coerced into brothels to serve as comfort women, many of whom were raped to death. In addition, thousands of allied soldiers were forced into hard labor and concentration camps. Following the war, the United States prosecuted many of the military leaders who perpetrated these atrocities at the Tokyo Trials. However, amnesty was 
also shown to many lower level war criminals in 1958 when thousands were rehabilitated and released back into society (UMBC, 2016).

Controversy persists to this day and many of the nations who suffered under Japanese colonialism and barbarism, feel that the nation has never fully, satisfactorily apologized for the crimes that it committed. In 1995 Japanese Prime Minister Tomiichi Murayama officially issued an apology for the crimes committed by Japanese military forces during the war (Wudunn, 1995). And in the past, compensation has been offered to certain victims. However, this has not satisfied many people, partly owing to the ongoing tradition of some high level Japanese politicians who have continually visited Shinto shrines where top Japanese war criminals are honored.

Shinzo Abe is the latest to have visited the controversial Yasukuni Shrine wherein the names of several Class A Japanese war criminals are kept, as per Shinto tradition. Abe's visits to the Shrine have done much to inflame and outrage neighboring nation's sensibilities, including China and Korea. Unfortunately, Abe has even expressed doubts as to the validity of the history of comfort women; many of whom, he claimed, entered brothels willingly (Reuters, 2016). From a diplomatic standpoint, the actions of Abe and other Japanese politicians does nothing to mollify China where anti-Japanese sentiment is already high. And from the stand point of forming an alliance, South Korea and the Philippines still harbor bad feelings, though in 2015 Japan finally officially apologized to South Korean comfort women and offered more than eight million dollars as compensation (BBC, 2015). Clearly, even after so many years, the legacy of Japanese war crimes still breeds mistrust and sours the diplomatic atmosphere.

It seems, then, that for Japan to take its place in any Asian-Pacific alliance, it must first shake off the past which still haunts it to this day. Alliances are, as Realists remind us, only 
temporary arrangements. They are inherently shaky and unstable and are only entered into if nations believe it is in their best interests. If the nations which surround Japan do not feel that their former enemy is fully repentant, they may not be inclined to join in an alliance with them. But if Japan can escape the restrictive bonds of its post-war constitution and come to terms with the crimes of its forefathers-to the satisfaction of its victims-then it may be able to take its place in an Asian-Pacific alliance.

\section{Challenge \#3: Straw that Broke the Eagle's Back}

The United States military is a truly fearsome entity to behold. Arguably the most powerful fighting force in history, few, if any, of the world's other militaries even begin to approach its size, scope or capabilities. In fact, the amount of money and resources that the United States spends and expends to maintain and improve its armed forces is simply breathtaking. The American military consumes a budget of over 600 billion dollars annually, a sum that accounts for some 50 percent of federal discretionary spending and 3-4 percent of national GDP. The United States maintains ten aircraft carriers, as many as the rest of the world combined (Walker D., 2014). It is through these aircraft carriers, as well as the worldwide network of bases and airfields maintained by the US, that allows it to project its military forces anywhere on earth, truly making it a global fighting force. And though its size has diminished over the years, the United States still maintains the most capable and powerful navy, air force, and army in the world. Still, though, could the United States afford to take part in an AsianPacific alliance? Already the American tax payer is responsible for more than the American military alone.

Every year, the United States Congress approves billions of dollars in military aid to various American allies around the world. Countries such as Israel and Egypt, the two largest 
recipients, receive aid packages worth more than a billion each, while other smaller countries receive only hundreds of millions of dollars (State Department, 2016). Besides its commitment to individual countries, the United States participates in the NATO alliance. The United States directly contributes 500 million dollars to the defense pact, which in and of itself is not much. However, the United States is one of only five NATO countries out of 28 total which meets NATO's minimum goal of 2 percent of GDP spending on defense. This deficit has prompted US officials to call for increases in those NATO members who fall short of the minimum (Kottasova, 2016). Until then, the United States continues to play an outsized role in NATO as it does in most of its defense relationships.

Clearly, the United States spends an incredible amount of money on not only its own defense but for many of its allies as well. The United States is the cornerstone of NATO as it was of SEATO. The question then naturally arises as to whether or not the United States could even afford to participate in an Asian-Pacific NATO-type alliance, especially considering its almost guaranteed oversized role in any such prospective organization as well as its already existing commitments. Just as it is the "hub" of today's quasi-alliance system, the United States would undoubtedly be the key player and the main force in any Asian-Pacific alliance. During the Cold War, the United States determined that balancing against the Soviet Union was vital to national security. It accomplished this balancing, in part, by enlisting the help of the nations of Western Europe. Today, in the face of a rising China, the United States would still be the key country that could tip the scales and balance the power equation of the Asia-Pacific region. Yet, without the backing of the United States, it is doubtful that any effective Asian-Pacific alliance could be formed. Unfortunately, for proponents of an alliance system, the ability of the United States to participate in such a system would, financially speaking, be very difficult. 
In 1991 the world was treated to the grainy visuals of cameras mounted on American smart bombs plunging into the key infrastructure, aircraft, and weapons of Saddam Hussein's Iraqi army. The United States stunned the world by deploying an ultra-modern Cold War military which eviscerated the opposition in a matter of weeks. In the following year, the Soviet Union was officially dissolved, leaving the United States with its state-of-the-art armed forces, as the undisputed "super power" of the world. As a super power, the United States has enjoyed what some scholars would describe as a "unipolar" world. Simply put, there has been no other country that could even begin to challenge us. Yet, the world has changed since 1991 and with it, the United States' position in it.

While the United States still maintains the most powerful military in the world, its invincibility is no longer guaranteed. Its position at the top of the global pinnacle was first shaken after 9/11. That searing event launched two wars in two countries which, even 15 years later, are still roiling in unceasing conflict. The financial costs of these two conflicts is almost incalculable. However, some studies predict that when all expenditures have been taken into account, both conflicts will have a final price 4 to 6 trillion dollars (Londoño, 2013). Yet it is not just the financial cost that has drained the United States.

The wars and deployments of the past 15 years have taken both a heavy physical as well as psychological toll. Most of the weapons that have been used in the War on Terror are the same systems that existed in the Gulf War. These Cold War era weapons have been endlessly retrofitted, repaired and sent back into combat. And in the year-after-year grind of ongoing war, billions of dollars' worth of equipment has become worn out and used up. Man, as well as machine, has also suffered. Soldiers have been sent on countless deployments and the cumulative effects have devastated both the service men and women and their families. Veteran suicides and 
post-traumatic stress related problems are through the roof, and though this may not be directly attributable to multiple deployments, they are some of the highest numbers ever recorded (Zoroya, 2016). This increasingly threadbare force is now also facing the reality of evershrinking budgets.

With the persistent effects of the 2008 financial crisis, terms like sequestration and budget cuts have become household words. With mounting debt and a slumping economy, Congress has been forced to tighten the belt, or at least threaten to do so. During the height of the Cold War, the military was provided with an almost blank check. But today the Pentagon is being pulled in two different directions: paying for ever-more expensive weapon systems while trying to find ways to creatively cut and sometimes hide military spending.

The high tech military of the Cold War is only getting more and more high tech. As technology advances at a rapid pace, the Pentagon is building increasingly sophisticated weapon systems. Yet paying for these technological leaps and bounds costs a lot of dollars and cents. The F-35 stealth fighter, as one example, is the military's cutting edge replacement for its aging Cold War squadrons. Yet unlike past jet fighter programs, the F-35 has turned into a nightmare, beset with delays and technical problems and, in the process, becoming the most expensive weapon in history. And it is not alone. Other programs such as the Navy's Zumwalt Destroyer, billed as the future of Naval combat, have reached costs so astronomical that many units of the previous generation of destroyers could be bought for the price of one Zumwalt. Due in part to the paymore-get-less predicament of modern weapons, combined with its shrinking budget, the Pentagon has had to cancel many other promising programs. From the cancellation of the arguably more capable predecessor to the F-35, the F-22 stealth fighter, to landing craft and helicopters, the military has seen a slew of next generation weapon systems scrapped due to high 
price tags and limited budgets (Bender, 2016). Just this year, Pentagon brass will have to cut an additional five billion dollars out of their budget (Gould, 2015). Yet, in recent years, both military leadership and certain congressmen and women, have found a loop hole through which to hide increases in spending.

The OCO, or Overseas Contingency Operations fund, is a supplemental military budget in addition to the Department of Defense's base budget. The OCO's express purpose is for providing emergency funding for operations or conflicts that occur suddenly and require the military to resolve. However, with more and more pressure on the base budget, some congressmen and women have adopted the practice of parking base budget line items in the OCO, thus avoiding having to make cuts. This shell-game of moving projects to different budgets has been a trick that the Obama administration has attempted to end (Davidson, 2015). Nevertheless, despite some rearranging of the proverbial deck chairs, the military has now shrunk to a size not seen since before World War II (Fox News, 2016). This is perhaps most dramatically illustrated by the US Navy which has shrunk from its Cold War high of 600 ships to just over 200 today (Jacobson, 2015). In fact, many experts have come to the conclusion that the US military would not be able to wage and win a so-called "two front war" as it did in World War II (Wiser, 2015). To add to this poor prognostication of the military's health, global events seem to be spiraling ever more out of control.

As if the depreciating effects of two wars and asphyxiating budget constraints were not enough, the United States is facing more threats to its national security and place in the world than at any time since World War II. China, one of the main focuses of this discussion, is moving aggressively in the Asia-Pacific region, seizing maritime territory and transgressing borders, all while building its military into a peer competitor of the United States. Russia is flexing its 
muscles as well throughout the world, while drawing ever closer to China and exchanging weapons technology and fostering what could become an alliance. Iran, though beginning to reenter normal relations with the West, still continually cries for the destruction of Israel and, many would say, continues to seek nuclear weapons. The other pariah of the international community, North Korea, is already armed with nuclear weapons. Its new leader, Kim Jong Un, possesses a questionable grasp on sanity and is leading what appears to be an increasingly unstable government and nation. Finally, ISIS, a supranational terrorist organization that seemingly sprung up from the ground like a mushroom, is now metastasizing in Syria and Iraq while committing attack after attack on innocent civilians all over Europe. To put it succinctly, the United States faces more threats than perhaps ever before, with a military that is the smallest it has been in a century.

Clearly, the trifecta of a war-worn, cash starved, overworked military is a recipe for a disaster. Neither the United States nor an Asian-Pacific NATO could hope to balance a rising China if they do not even have the money to maintain a modern military. Also clear is that any Asian-Pacific NATO-type alliance, as with the actual NATO, would demand a sizable role for the United States. There are several potential Asian-Pacific alliance members who have advanced and prosperous economies. Japan, South Korea and perhaps Taiwan, are all first world countries that can afford modern expensive militaries. But other potential alliance members, such as the Philippines and Vietnam, would struggle to field even a fraction of what is needed to defend them and their possessions in the South China Sea. Just as with their NATO counterparts, there would be many members of the Asian-Pacific alliance who would struggle to meet basic defense spending requirements. A serious question arises as to whether or not the United States 
can afford yet another commitment on its scarce resources. Overcoming this problem would be essential before even considering an Asian-Pacific NATO.

\section{Challenge \#4: Nine Dashes Behind the Eight Ball}

Any potential Asian-Pacific NATO would need to decide what it would protect and what it would leave undefended. This, though, is complicated by the complex territorial environment of the South China Sea. Unfortunately, in this respect, the original NATO did not face an exact parallel. In the opening chapter of the Cold War, the countries of Western Europe faced a frightening prospect: Soviet domination. Already, the nations of Eastern Europe had been rolled up and "liberated" by the Russian megalith which was now poised to do the same to Western Europe. Exhausted by conflict and seeking to hold off the "Red" war machine, France, Great Britain, Belgium, Luxemburg and the Netherlands signed the Treaty of Brussels creating a Western European defense pact. Armed with this treaty, the signatories were guaranteed that each member would come to the other's defense in case of an invasion or attack by an outside power. But the treaty was as thin as the paper on which it was printed. The treaty was clearly drafted with the Soviet Union in mind, but the signatories were so weak, they could never hope to hold off Soviet forces, even together. To wage a credible defense and deterrent, they needed more firepower (Fenton, 2012).

Out of this dearth of military power emerged NATO. One of the chief reasons for the creation of NATO was to include the United States and its powerful armed forces. With US forces in Europe, a credible defense and deterrent was established. The legal mechanism through which this deterrent was established was Article 5 of the NATO treaty. Much like its forbearer, the Treaty of Brussels, Article 5 of NATO guaranteed mutual defense and aid by all if any one member came under attack (MacCloskey, 1967). Thankfully, in the forty-plus years of the Cold 
War, Article 5 was never invoked. Perhaps the reason for the stability and peace maintained between the East and West was due in part to the stability of the borders.

The Soviet Union, for all intents and purposes had invaded Eastern Europe during the fog of World War II. However, in the tense days following the end of the war, borders stabilized and solidified, becoming impenetrable barriers of barbed wire and concrete. The Iron Curtain was clearly demarcated, and crossing it would have been a blatant, explicit action. Yet in the new Cold War that is shaping up in Asia, the borders are not so clear.

In many ways, the threat is still the same: a single country, expanding its borders and territory through aggressive actions. Yet the borders in the South China Sea have definitely not settled or solidified into any new "Iron Curtain." Instead, the nautical boundary lines of each South China Sea claimant nation are overlapping and tangled together. The entire purpose of an Asian-Pacific NATO-type alliance would be for mutual protection against an aggressive China. But what, exactly, would the alliance protect? How can borders be defended if the boundaries of those borders are in question?

One of the first challenges to be dealt with by an Asian-Pacific alliance would be the legitimacy of different kinds of claims. Historical claims are perhaps the most prominent. In particular, China's nine-dash line dominates any conversation regarding the South China Sea. The nine-dash line is the device China has used to proclaim its absolute sovereignty in the South China Sea. Based on ancient traditions and documents, the nine dash line overlaps every other nation's territorial waters in the South China Sea. Within this line, China has constructed its infamous artificial islands, spewing dredged-up sand and rock onto pristine coral reefs. How, then, should an Asian-Pacific alliance respond to these actions and claims? Would the alliance recognize the legitimacy of these claims? 
One body that has certainly not recognized the claims of China is the Permanent Court of Arbitration. A mainstay of over one hundred years for nation-states seeking to resolve their disputes, the Court regularly settles international boundary disputes. In 2013 the Philippines brought before the Court its claims to the South China Sea, to be arbitrated and settled. China did not take part in the proceedings, claiming that the Philippines had violated previous treaties by inviting third parties to settle the dispute. Incredibly, China is a party to the Permanent Court and officially recognizes its legitimacy. Despite its official recognition of the Court, China flatly rejected the Court's finding in favor of the Philippines (PRC, 2016) (Denyer, 2016). An AsianPacific NATO-type alliance would have to decide whether or not to recognize the Permanent Court's ruling. If it did, it would leave it with the official position of rejecting the entire nine dash line. It would then be faced with the dilemma of how to respond to not only existing artificial islands, but potential future ones as well.

But China, by basing its claims on ancient documents, is simultaneously violating modern maritime rights and well as the Court's decision. Up to 12-miles from the shore of a nation are the sovereign waters of that nation. Crossing over into or violating those waters would be akin to crossing a border on land. Within these sovereign waters, a nation can exercise absolute control. However, extending 200-miles from the shore line is a nation's exclusive economic zone (EEZ). Within that area, the country in question does not have an absolute right to oversee who enters, but does have exclusive rights to exploit the natural resources of the waters. Ships from other nations may cross into this EEZ, but they may not fish or conduct any other economic activities without the express permission of the host country. Both sovereign and exclusive economic zone waters were established by the United Nation's Law of the Sea Treaty. 
And all claimants to the South China Sea, including China, are parties to the treaty; that is to say, that they recognize the treaty as international law (PCA, 2016).

But China has broken this law. Not only has China built artificial islands using a discredited map, but it has built several of them inside of the 200-mile EEZ of the Philippines, an act completely illegal under the United Nations Law of the Sea. And the People's Republic has not only built these artificial and illegal islands, but has also taken the step of repeatedly blocking the lawful exploitation of economic resources in Philippine waters by harassing and cutting off Filipino fishermen from their traditional fishing waters. However, this violation of international law did not happen overnight. There are many coral reefs both in and outside of the Philippine's EEZ that have been occupied by China, and many of them have fallen to China in the same way (PCA, 2016).

Mischief Reef, for example, was once administered by the Philippines. Philippine fishermen and naval vessels exploited and patrolled the waters in and around Mischief Reef for decades. But then everything changed. The Philippines had been a large and vital strategic base for the American Navy. Despite this, in 1991 the Philippine government ejected all US personnel and closed all US naval and air force bases. It didn't take long for China to exploit this selfimposed isolation. In 1995 China took advantage of the Philippine navy's absence during the monsoon season and constructed a crude ramshackle collection of stilted huts in the shallows of Mischief Reef. Seeking to avoid an international incident, and reassured by the Chinese that the structure was merely a refuge for fishermen, the Philippines accepted the seemingly innocuous toe-hold. But these shaky huts would soon be replaced by a large concrete outpost in 1999. This pattern was repeated on other islands throughout the South China Sea, as China constructed various structures on shallow potions of contested reefs. Finally, Mischief Reef was completely 
transformed in 2015 and 2016 when dredging ships piled sand on the shallow coral, turning it into a man-made island. Now Mischief Reef boasts an airplane runway as well as multiple structures and installations. The transformation of Mischief Reef has been shocking if not awe inspiring. The Chinese have established a strong and seemingly permanent presence on Mischief Reef, a presence within the Philippines' 200-mile EEZ (CNAS, 2016). But Mischief Reef is not the only Philippine possession that has been targeted by Xi Jinping's China.

Second Thomas Shoal and Scarborough Shoal, both claimed by the Philippines and both in Philippine's EEZ, are threatened by further Chinese expansion. The Chinese have effectively seized Scarborough blocking entrance to all Philippine vessels, a familiar tactic. However, just as with Mischief Reef, Scarborough Shoal belongs to the Philippines, though in practice, the Chinese exercise absolute control. At Second Thomas shoal, the story is somewhat different. There, a ragtag band of Filipino marines posted on an ancient beached Philippine navy ship that is little more than a rusted shell, act as sentries keeping Chinese forces from conquering the reef. Circling this rusted, immobile hulk are, ironically, Chinese coast guard ships (perhaps in itself a message) in a long waiting game to see who can last longer. The marines are only infrequently resupplied, as the Philippine navy is often too timid to confront the Chinese vessels.

Nevertheless, this desperate outpost has, so far, halted the Chinese advance. But for how long? How long until the circling communists tire of the stand-off (Himmelman, 2016)?

If an Asian-Pacific NATO comes into existence, it must decide where to draw the lines. It must decide what "Article 5" is worthy and what is not. If the alliance commits to protecting the integrity of the 200-mile EEZ of its members (which would undoubtedly include the Philippines) then it must approach the current situation very carefully. It may decide to let the Chinese continue to occupy Mischief and Scarborough while drawing a line at other reefs such as Second 
Thomas. It may pull back only to sovereign waters within 12-miles of the coast, or it could go on the offensive, cutting off artificial islands like Mischief and instigating a second Cuban Missile like crisis. Realist theory predicts that states are inherently suspicious of each other. Furthermore, in a multipolar world, such as we now live in, the possibility of a mistake leading to war is greatly increase. These theoretical realizations, combined with the tensions in the South China Sea, makes for an incredibly dangerous environment. Clearly, the decisions on where to draw the red lines, which islands to protect and which to let go of, are questions of vital importance and one of the most important and complicated challenges to forming any kind of Asian-Pacific alliance and achieving a Realist balance of power in the region.

\section{Challenge \#5: Blow Back}

Actions taken by an Asian-Pacific NATO could result in unintended consequences. But consequences are always a risk when military and intelligence organizations make decisions. In fact, in the espionage and national security community there is a term for unintended consequences that result from covert operations: blowback. Blowback was a term coined by the CIA to describe the unforeseen complications that their top secret missions would invariably produce. Perhaps the most classic example was the creation of Al-Qaeda. During the 1980's the Soviet Union invaded and occupied Afghanistan. After installing a pro-Soviet puppet state, the Russian troops battled an aggressive and persistent insurgency. But the Mujahedeen were not just formidable because of their tenacity. Armed with CIA supplied American stinger missiles, the Afghan rebels were able to defeat the advanced ground attack helicopters of the Soviet Union which had been decimating their ranks. However, despite achieving the withdrawal of Soviet forces in 1989, the CIA had unknowingly created a monster. More than a decade later, elements of the Mujahedeen, combined with other radical Islamists, struck the World Trade Center towers 
in New York, killing thousands (Bergen, 2005). Unintended, unforeseen, and even unwanted consequences are all a part of the strategic and military decision making process and sometimes they are simply unavoidable.

In Realist theory, the concept of blowback is more commonly described as a security dilemma. Security dilemmas take place when the actions of one state to strengthen its' defenses, such as building an alliance, spurs opposing states to strengthen their security and take similar measures. This ping-pong action can turn into a spiral as each nation attempts to gain an edge over the other. In the end, an attempt to make your country more secure does just the opposite as your enemy seeks to match or exceed your capabilities. During the early days of NATO, there was much talk of including West Germany in the defense pact. Western military planners felt that absent West German manpower, it would have been almost impossible to have protected Western Europe from a full scale Soviet invasion. Yet the proposition to rearm and redeploy West German armed forces did not come without serious opposition from within and without NATO. Both France and the Soviet Union, who had lost millions of soldiers fighting Nazi Germany, strongly protested the inclusion. The Soviet Union even attempted to join NATO due to its fears of a rearmed Germany. This attempt was, of course, rebuffed by NATO, who perceived it as a ruse to undermine the very purpose of the defense pact. France, in its way, also tried to prevent the admission of West Germany. It proposed a new defensive alliance ${ }^{1}$ that would include German forces while simultaneously stripping West Germany of its ability to command those very troops. This plan, too, failed to garner much support and eventually fell apart, leaving the way open for the full inclusion of West Germany into NATO (Duignan, 2000).

\footnotetext{
${ }^{1}$ The European Defense Community (EDC)
} 
The inclusion of West Germany into NATO and its subsequent rearmament, spurred the Soviets to create their own defense pact. The Warsaw Pact was signed 1955 in Warsaw, Poland and brought together the Soviet Union and the majority of its satellite states under one defensive umbrella. Like its Western adversary and counterpart NATO, the Warsaw Pact guaranteed that an attack on one member would be considered an attack on all. Throughout the rest of the Cold War these two steely-eyed confederations would be locked in a tense stand-off until the eventual demise of the Soviet Union. The two armed giants never did engage in combat, and about the most action that Warsaw Pact forces ever saw was the internal suppression of uprisings in Czechoslovakia. And while some question the efficacy or even the Soviet need for the Warsaw Pact, few question the impetus for its creation (Gaddis, 2005). With this historical lesson in mind we must ask: would the creation of an Asian-Pacific NATO-type alliance precipitate a "blowback" response from the Chinese? Would the Chinese create their own alliance or become more aggressive?

Much like the Soviets sixty years ago, the Chinese are already wary of any sort of alliance being formed against them. In a revealing interview with the Wall Street Journal, Chinese ambassador to the United States Cui Tiankai characterized the US's bilateral "hub and spoke" defense pacts with various Asian-Pacific nations as "anti-China." He continued to say that the formation of any alliances that were aimed against China were counterproductive and "stupid" (Horvath, 2015). Clearly, the Chinese Politburo is sensitive to any sort of push back or talk of containment. The question then arises: would the Chinese form their own Warsaw Pact to counter an alliance in Asia, or would they take even more aggressive actions?

There could be a number of reasons that the Chinese would form their own alliance. Seeing the creation of an Asian-Pacific alliance as inherently "anti-China," in the same way they 
now view American bilateral agreements, Chinese leaders would perhaps move to counter it by developing their own equivalent. Or, such as was the case with the creation of the Warsaw Pact, the inclusion of a specific member could be the trigger. As we have seen, the Japanese still carry a lot of baggage from their imperial days. Not only China, but many other regional nations harbor bad blood against Japan. China, in particular, hosts the most vehement anti-Japanese sentiments in the region. These are, in large part, encouraged by the Communist Party to serve their own agenda, and are also spurred on by nationalist outcry over the Senkaku Islands dispute. As such, anti-Japanese feelings in China are at an all-time high. China is especially sensitive to developments and changes in Japan's defense posture. Increases in Japanese defense spending under Shinzo Abe, have been criticized by Chinese observers and government officials, as have policy changes allowing Japanese armed intervention in defense of allies. Even certain ships built for the Japanese Navy have been met with suspicion. With the completion of a new helicopter carrier ship, some Chinese commentators breathlessly declared it a full blown aircraft carrier, something traditionally prohibited by the Japanese constitution (Gamble, 2016). It is easy to see, then, that the inclusion of Japan into an Asian-Pacific NATO organization, and its possible full rearmament, would have the potential effect of inflaming the Chinese, and could even precipitate the building of a Chinese alliance. But what would such an alliance look like? In fact, the framework may already exist.

The Shanghai Cooperation Organization (SCO) is a relatively new organization founded by China, Russia and several Central Asian nations. Created initially as more of a forum to address contentious border disputes, the SCO has evolved into a regional economic, political and defense organization. One of the primary missions of the SCO is to combat the "three evils": terrorism, extremism, and separatism. Terrorism and extremism undoubtedly arose in a post 9/11 
environment. However, the commitment to combating "separatism" is especially alarming considering China's relationship with Taiwan and its view of that island as a rogue province. Nevertheless, the SCO underlies the close relationship that has been developing between the Peoples Republic of China and Putin's Russia (Albert, 2015).

Both nations increasingly find themselves coloring outside of diplomatic (and territorial) lines. China's actions in the South China Sea have been condemned by the Permanent Court of Arbitration, while Russia's actions in Ukraine and Syria have likewise been criticized. In this environment, the two rebuked nations draw closer, sharing weapon's technology and voicing support for each other in international forums. Though China has built a substantial military industrial complex and produced many different homegrown weapons systems, it still draws heavy inspiration from Russian designs. In fact, China's one and only aircraft carrier is a Russian built ship, and for the foreseeable future, it is highly likely that China will continue to benefit from Russian weapon imports and licensing (CISIS, 2016). But the military relationship of the two nations is not only limited to technology exchanges. In September of 2016, both nations will hold a large naval wargame exercise in the South China Sea, a provocative action considering the tensions there (Page, 2016). Besides the closer military ties of both Russia and China, the economic dimension of the SCO is also being strengthened, stitching the member nations together through trade and commerce. In 2015 the Russian state-owned oil and gas giant, Gazprom, and the Chinese National Petroleum Corporation (CNPC) signed a multi-billion dollar contract to supply energy-hungry China with Siberian natural gas (Rapoza, 2015). The alliance of Russia and China would, without a doubt, be a formidable adversary. Yet a counter alliance is not the only form that an Asian-Pacific NATO blowback could take. 
China is, in its own right, a very powerful nation. With a population of over one billion people and second largest economy in the world, China has the fortitude and resources to stand on its own. The formation of an alliance arrayed against China could spur them into taking aggressive, unilateral actions. For one, the Chinese could resume the island building projects in the South China Sea, capturing and constructing artificial islands and, in the process, create an international crisis. Or, Chinese strategists could take a more subtle approach.

Currently, the Chinese government is developing, or trying to develop, ports in several nations that ring the Indian Ocean. Harbors, such as the Gwadar port in Pakistan, have received significant Chinese investment money to aid in infrastructure development. These ports are, ostensibly, for the furthering of China's ambitious "One Belt, One Road" trading plan, whereby China seeks to develop closer trading ties to various Eurasian nations. However, some have speculated that these ports could be developed for military purposes just as easily as for economic ones. Under this interpretation, the Chinese, as one US think tank termed it, are creating a "String of Pearls;" a series of naval bases encircling the Indian Ocean, thus giving the Chinese tremendous strategic leverage. This "string" would start in the South China Sea before snaking its way along various coasts to the tip of Africa (Baker, 2015). Any such arrangement would allow the Chinese to secure their Middle Eastern Oil Supply while also threatening the flow to its neighbors.

The Chinese navy would also greatly benefit from any such plan. As of now, the Chinese navy is hemmed into the East and South China Seas by the First and Second Island chains. The first Island chain consists of Japan, Taiwan, the Philippines and Indonesia, almost all of which host American or other naval forces potentially hostile to China. The Second Island Chain is populated by much smaller islands, the most important being Guam. These surrounding naval 
and military forces act to bottle up China in its own territorial waters and, in a time of war, could be used to completely blockade the nation (Navarro, 2015). But, if significant Chinese forces were based in the Indian Ocean, this containment strategy would be far less effective. In a sense, if the Chinese responded to an Asian-Pacific alliance by making the String of Pearls a reality, the conflict which heretofore has been contained to the East and South China Seas, would greatly expand in scope, taking on global proportions.

Would an Asian-Pacific NATO still be strategically desirable in the face of such significant blowback? Could an Asian-Pacific NATO cope with a robust and hostile SCO or with the expansion of Chinese naval assets into the Indian Ocean? Or, would it be better to simply fall back on the tried and true Hub and Spoke system in an attempt to quiet Chinese tensions? The purpose of an Asian-NATO is to balance the rise of China. However, as some Realists predict, doing so can precipitate a security dilemma. The nations surrounding China may very well be successful in building an alliance, but doing so could spur China to pursue more aggressive defensive strategies, exactly as Realist theorists would predict. 


\section{CHAPTER III: THE SOLUTIONS}

In this chapter, we will examine potential solutions to the challenges examined in the last chapter. The original NATO was able to successfully justify its existence simply because it was needed. Likewise, an Asian-Pacific NATO could make a strong case for its creation by the fact that alliances have many benefits currently not present in the hub and spoke system. Second, NATO made the controversial decision to include West Germany in the alliance. Likewise, an Asian-Pacific NATO would have to make the decision to include Japan in its alliance. However, the barriers and repercussions of doing so could be mitigated. Like its European counterpart, an Asian-Pacific NATO would need to spend more on defense but it could do so effectively by refocusing its priorities and purchasing more cost effective weapons. Territorial disputes, while virtually unknown to the original NATO, would be a paramount concern to an Asian-Pacific NATO. By staking out red lines and appealing to international law, an Asian-Pacific NATO could make great progress in lowering tensions. Finally, as the original NATO had to face the blowback of the Warsaw Pact, an Asian-Pacific NATO could be confronted with significant blowback from China. However, as the original NATO demonstrated, sometimes it is best to simply whether the storm.

\section{Old NATO, Old Solutions}

The original European NATO was confronted with many challenges of its own. From justifying its own existence to including such controversial members as West Germany, it was confronted with a myriad of difficult challenges. Yet, in each instance, it managed to resolve most if not all of them. Identifying how it solved these challenges gives us insight into how our hypothetical Asian-Pacific NATO might solve its challenges as well. 
Returning to the first challenge, the nations of Western Europe were already protected by the Treaty of Brussels and the defense pact that was drafted as a result. Why then was NATO even needed? In fact, the founders of the Treaty of Brussels themselves pushed for the creation of NATO. The Treaty of Brussels lacked one vital and indispensable member: the United States. NATO was justified on the basis of the inclusion of the United States. Without the United States, Europe lacked a credible deterrent and could not possibly hope to balance against the Soviet Union. Thus the challenge of justifying the creation of NATO was an easy argument for the founders of the defense pact. Turning to the inclusion of controversial members, this too was a challenge met by NATO. West Germany was needed to help secure Europe and balance against the Soviet Union. Just like the United States, West Germany was indispensable. Yet, despite the protests of some countries, NATO successfully absorbed the military of West Germany and in doing so, solved the imbalance of power with the Soviet Union (Gaddis, 1998).

The Challenge of the affordability of military expenditures was also met by the members of NATO. NATO forces were consistently able to outspend their Soviet counterparts and thus win the Cold War. Military expenditures were also mitigated by prioritizing what to defend. However, sometimes deficit spending was required for the strategy of out spending the Soviet Union to work. During the Cuban Missile Crisis, the United States and NATO were faced with the prospect of Soviet nuclear weapons stationed off the coast of the continental United States. These weapons threatened the territorial security of the United States and thus NATO. Yet, the Soviet Union had already been put in the same position by the United States who had stationed weapons in Turkey, close to the borders of the Soviet Union. Both nations agreed to remove their respective weapons and thus preserving the territorial integrity of their respective nations. Finally, NATO had to contend with the challenge of blowback that resulted from its action to 
include West Germany in its alliance. The Soviet Union, fearing a resurgent Germany, reacted to the inclusion of West Germany by constructing its own defensive alliance, the Warsaw Pact. Yet, just as NATO had balanced against the Soviet Union for decades, it continued to maintain balance even with the Warsaw Pact. The effect of the blowback was mitigated and successfully contained (Gaddis, 1998).

Thus, the original European NATO managed to consistently solve the numerous challenges that confronted it throughout the Cold War. Surprisingly, many of them were similar to the challenges that could potentially face an Asian-Pacific NATO today.

\section{Solutions for a 21st Century Asian-Pacific NATO}

In this section we will examine solutions to the five challenges facing an Asian-Pacific NATO. First, the hub and spoke system, while mimicking an official alliance, does not provide the same benefits that an actual alliance would. Secondly, the impediments between Japan and its inclusion in an Asian-Pacific alliance are shown to be completely surmountable. Third, the cost of an Asian-Pacific NATO-type alliance can be better absorbed by the United States through a reprioritization of vital interests and focusing on more cost-effective weapons. Fourthly, territorial disputes can be resolved, or at least made more manageable, through the use of international law and the ruling of The Hague. Finally, there may be no simple solution to blowback. Instead, an Asian-Pacific NATO would possibly have to simply absorb the consequences of its actions.

\section{Hub and Spoke Solution}

Returning to the challenge of the apparent sufficiency of the Hub and Spoke model, we remember that the United States maintains a formidable quiver of bilateral alliances. Some of the most advanced nations in Asia enjoy mutual defense pacts with the United States, thus greatly 
boosting their national defenses. Furthermore, many if not all experts advocate for a strengthening of the Hub and Spoke system with its bilateral relationships. They believe that the bundle of American alliance countries is sufficient to maintain and attain a balance with a rising China. But relying on the hub and spoke system is like riding a bicycle with only a hub and spokes: you won't get very far.

Looking at the combined firepower of the American hub and its Asian spokes, it is, at first, hard to see where there is even a need for an Asian-Pacific NATO. However, alliances, bilateral or other, and defenses are about more than just physical guns and ships. Balance of power, as explained by Cold War expert John Lewis Gaddis, is not always based on actual power as much as it is on the perception of power. Sometimes, security is reliant on your enemy's perception of your power as much as it is on your actual power. Alliances, apart from being the combined fighting forces of many different nations, are, in and of themselves, potent statements. They serve to put adversaries on notice, and at the same time, reassure allies. At their core, alliances are tasked with two objectives: to deter and defend. Defenses are obvious enough. They are what we can see and count; they are the assets which are readily converted into tables and graphs. But deterrence is somewhat more immaterial. Deterrence is based on defense, but it is different. Deterrence is the mechanism by which the use of defensive forces is unnecessary. And an alliance that can successfully deter its enemy is a successful alliance (Gaddis, 2005).

An Asian-Pacific NATO may not greatly expand the physical capabilities of Asia's individual armed forces, but it would serve as a powerful deterrent. The perception that the combined armed forces of an Asian-Pacific NATO projected, would create a powerful deterrent; making any country think twice before engaging in illegal actions in the South China Sea. Boundaries are not so carelessly transgressed when an adversary believes that there would be 
consequences. As of now, these consequences are left up to one nation to deal out: the United States.

As the hub of the hub and spoke system, the United States is the fallback power for almost every nation in the region. This, of course, puts tremendous pressure on the United States, while leaving other powers free to off-load responsibilities. If the Philippines were to be attacked, it would be the United States alone who would be obligated to come to its aid. Likewise, if Japan was blockaded, or South Korea invaded, the United States would be the sole power to respond. As we have discussed, the United States is already under considerable pressure globally, and waging a full scale war in Asia would strain its already overtaxed forces. However, a true multinational alliance would help to spread the burden. Previous military planners saw the necessity of spreading defensive burdens when they brought West Germany into the NATO fold. Absent West German manpower, Western leaders did not see how they could repel a Soviet invasion. Just as part of the NATO burden was shared with West Germany, the American burden could be shared with fellow members of an Asian-Pacific NATO in a way that it is not true at this present time (Gaddis, 1998). If one spoke is attacked, all spokes respond. But to have this collective response, you need to have a collective fighting force.

During the Second World War, the allied armies banded together to defeat Nazi Germany and Imperial Japan. And while the mission of these allied armies was the same, the equipment they used to complete their mission was not. Each army used different ammunition and maintained different standards for communication and strategy. Today, however, the European armies of NATO have standardized almost every aspect of their militaries. From bullets to gasoline blends, the entire logistical infrastructure is interchangeable within all member nations. STANAG, or Standardization Agreement, is the process by which NATO has standardized its 
fighting forces. But far from simply standardizing things that go boom, STANAG has made compatible almost every facet of military operations. Everything from the procedures for landing fighter jets to the type of radios frequencies used, all are NATO standard. Thus, in the din of battle, the combined armed forces of NATO would (in theory) meld into a single cohesive fighting force (NATO, 2015). Standardization is important but it is only one piece of an alliance puzzle. Centralization is equally important as well.

In a hypothetical NATO war, French, British and American forces would not be commanded at the top by French, British and American commanders but by NATO commanders (MacCloskey, 1967). This centralization, like standardization, ensures that NATO can function as one army. Even though most of the armies that the United States has defense treaties with use NATO standardized equipment, an Asian-Pacific alliance STANAG agreement would ensure that this standardization is complete and comprehensive across all forces. Furthermore, an Asian alliance would provide for the centralization of command and decision making. Rather than having disparate and dis-unified spokes, an alliance system would be able to harness the combined power the East and Southeast Asian nations into a very large and competent fighting force.

Separately, the spokes of the current hub and spoke system are relatively weak. But bound together, like a Roman fasces, the alliance of spokes would be a powerful deterrent, creating a check against further Chinese expansionism. Not only would the perception of allied power be greatly expanded but, in actuality, the combination of forces would create a sum greater than its parts. By forging a common fighting force, an Asian-Pacific NATO would give the armies threatened by China capabilities they did not heretofore possess and achieve a Realist 
balance of power. The hub and the spokes would finally become a wheel and, in the process, take an alliance much further down the road to security.

\section{Two Yurei Solution}

Japan, as we have explored previously, is a very economically and technologically advanced country. With the third-largest GDP in the world, Japan would certainly be one of the most capable and powerful alliance members in an Asia-Pacific Alliance. However, as we have discussed before, Japan is constrained by two "ghosts" from its past that still haunt it to this day. Both the Japanese's pacifistic constitution and the legacy of war crimes committed against their neighbors limits Japan both legally and diplomatically from assuming its hypothetical role in an alliance and from an expanded defense role in the here and now. Yet, turning to the question of constitutional restrictions, there may be fewer impediments than commonly thought.

Following the Japanese defeat after the War, the occupying US forces under General MacArthur tasked the defeated government with drafting a new constitution. However, traditionalist Japanese politicians, schooled in an era of imperialism, attempted to paper over the most objectionable portions of the old Meiji era imperial constitution, a tactic which did not impress MacArthur. After encountering the stubbornness of the Japanese political establishment, MacArthur tasked his team with drafting a new constitution. The resulting document, which severely limited Japan's ability to maintain conventional armed forces, is still largely in force today and has become a fixture of Japanese foreign policy and political thought. Yet, early on, the very conquerors who wrote the constitution pressured Japan to abandon its pacifist articles (Sugita, 2003).

During the early 1950's, as the United States was engaged in the Korean War, it became clear to both the US and the Japanese that the United States could not indefinitely provide total 
protection for Japan. The United States was, at that time, concluding its occupation of Japan and preparing to return sovereignty to the government and conclude a peace treaty with the island. But with the emergent threat of Communism in Asia, the United States started to have second thoughts over the pacifist elements of the constitution they had bestowed upon the Japanese. In a remarkable policy turnabout, Secretary of State John Foster Dulles pushed Japanese Prime Minister Yoshida hard to commit Japan to a rearmament plan. US delegates even went so far as to suggest amending the constitution to largely do away with the pacifist Article 9. Yoshida argued forcefully, yet diplomatically, that Japan was in no position economically to rearm, and furthermore, feared the birth of a resurgent Japanese militarism should that position be pursued. He even feared that a reinvigorated and rearmed Japan would alarm its neighbors and upset the security and diplomatic post-war equilibrium that Japan had worked to build. Yet Dulles continued to push him until the two came to a workable agreement. Japan would begin to build a national police/ defense force (Sugita, 2003).

Today, this defense force is, in fact, a full blown military. Despite several largely selfimposed restrictions on different types of weapons, Japan wields an impressive amount of power. And the rules governing the exercise of that power are becoming more and more permissive. Japan has loosened regulations on arms exports, hawking their stealthy diesel submarines, patrol boats and radar planes to a slew of Asian-Pacific countries. The Japanese Diet has also passed legislation reinterpreting Article 9 and allowing for Japanese armed forces to assist allies in a time of war. The simple fact is that today, Article 9 is a hopelessly obsolete law from a different era. Yet, even in the era in which it was written, American policy makers thought it outdated. Even Shinzo Abe, in pushing for greater liberties to create a modern military, has remarked that a 
strict reading of Article 9 expressly prohibits the defense force currently maintained by Japan (Mie, 2016).

The line between defensive and offensive weapons is a subjective one, and with increasing brinksmanship from China and the dangerous behavior of North Korea, Japan may find itself only a few "interpretations" and "revisions" away from finally retiring their pacifist past. When the final nail in the coffin of the old pacifist elements of Article 5 is hammered in, it will be due more to the overcoming of Japanese attitudes than constitutional provisions. Another attitude that prevents the exorcising of the last "Yurei," or ghost, is a persistent reluctance on the part of some Japanese to fully account and atone for Japanese war crimes.

It's hard to forget the horrors of the World War II but some would rather pretend they never even happened. The conservative establishment in Japanese politics has pushed hard for revisions in the pacifist Japanese constitution, yet they have also attempted to revise history as well. And while there have been past Japanese political administrations that apologized for Japanese war crimes, some politicians, such as Abe, have attempted to minimize practices such as the kidnaping and keeping of "comfort women." (Woo, 2016) This denial has chilled relations between Japan and her neighbors, both friend and foe. Yet relations may be starting to thaw already. Japan has, as we have seen, created a program to provide reparations to South Korean women who suffered in Japanese brothels. But some still feel that there has not been a full repentance; a moment where the Japanese government fully admits the scope of its past crimes.

In 1970 German chancellor Willy Brant was in Warsaw, Poland for the signing of an historic treaty. It was there he visited the Warsaw ghetto memorial to pay his respects to the victims of the Nazi invasion. In an apparently spontaneous move, Brant knelt down on his knees before the memorial in a show of deep contrition and respect. This act, known as Kniefall von 
Warschauhas or German Genuflection, has itself been memorialized and represented both a coming-to-terms with, and apology for, German war crimes. Abe need not necessarily kneel before any monument, but many feel that the Japanese need their own Kniefall moment: an undeniable act that helps to heal the past and close that awful chapter in Asian history (Browne, 2015).

The past need not be a ball and chain for Japan. Japanese aggression was only one chapter in the fantastic history of the people of those islands. And it need not dictate their future in perpetuity. The Japanese must overcome this history and take their place as an unencumbered and equal country in the community of nations. It can be done, and, for the safety and security of the Japanese islands it must be done.

\section{The Eagle's Back Solution}

The United States military is, without a doubt, at one of its lowest points in its two hundred-plus year history. Especially by Cold War standards, it is an anemic, underfunded organization, continually putting off the purchase of new weapon systems while refitting existing ones. Like a rag and bone man, it strips spare parts from junk yards to keep old planes flying and ships floating. And the ultramodern replacements for existing systems are so expensive that too few are purchased to fully replace existing numbers. Add to this the United States' excessive commitments and conflicts in which it is engaged, and the idea of joining yet another alliance seems to be too tall an order. Yet, just as military planners in a post-World War II environment had to make sacrifices and cutbacks, today's military will have to re-evaluate its priorities in order to meet the new challenges of the 21 st century.

Massive amounts of capital and money were expended by the United States during the long decades of the Cold War. Technology increased at a dizzying pace partly due to the 
enormous R\&D costs of the continuous arms race between the United States and the Soviet Union. This game would ultimately tax the Soviet system one too many Rubles, causing the entire Communist confederacy to fold. The United States, on the other hand, did not crumble or even suffer any adverse effects from its spending spree. On the contrary, the decade following the end of the Cold War saw America enjoy an economic boom. Of course, part of this dichotomy can be explained by the Capitalist system the United States used as opposed to the Communist one of the Russians (Gaddis, 1998). Yet the Americans also made smart decisions early on in how they would fight the "war," decisions that should be re-evaluated for their usefulness today.

As the United States was moving from basking in the light of an Allied victory to the post-War reality of an ascendant and aggressive Soviet Union, it needed a guide to help it make the transition. This unlikely guide was a diplomat holed up in the American embassy in Moscow. George F. Kennan was a Realist in every sense of the word. A straight-shooting, "tell it like it is" kind of person, Kennan got the chance to tell Washington just exactly what he thought of the then-American policy towards the Soviet Union. Kennan shocked the Washington establishment with his "long telegram," elucidating the intentions of Soviet planners and politicians in stark terms. Among Kennan's many contributions to American Cold War policy was his demarcation of American interests as they relate to American foreign policy (Gaddis, 2005).

Unlike some today who might advocate limitless missions for the United States, Kennan was quick to point out that American foreign policy must be dictated by vital interests. With limited resources, the United States simply could not afford to be all places at all times, combating every form of evil and injustice. He advocated that the United States was best suited by a "wise economy in the use of [its] strength." In this vein, he proposed that the United States 
focus on protecting the great industrial centers of the world. Western Europe, North America and Japan were vital to protecting American interests, and they could not, under any circumstances, fall into Soviet hands (Gaddis, 2005). Today it might be time to reevaluate what we consider to be our vital interests.

The United States has committed itself to the defense of dozens of countries the world over and is simultaneously involved in countless conflicts and low intensity wars. From drug wars in Columbia to military exercises in Latvia, and foreign aid to Pakistan and Afghanistan, there is hardly a country on earth that doesn't have some kind of American military presence. And these hundreds of commitments cost hundreds of millions of dollars. The Obama administration's "pivot" to Asia represented a strategic re-centering of American foreign policy (FPI, 2016). It recognized the primacy of the Asia-Pacific region to American economic prosperity and security. Nevertheless, any pivot is twofold: in order to focus on one thing, you must take your attention off of another. If the United States is going to make a significant contribution to Asian security, it must draw down its commitments in other parts of the world. This could mean a myriad of things, but may include actions such as a reduced presence in the Middle East where, in an age of increasing American energy independence (Yergin, 2013), Gulf State oil becomes less of a strategic concern. Or, perhaps, it may mean beginning the process of a détente with Russia, with the realization that Ukraine and Crimea exist within Russia's sphere of influence and are not a vital American interest. Whatever shape it takes, American policy makers would do well to adopt Kennan's "wise economy" strategy in determining where to focus US power in the world and where to draw down. No matter where we focus American power, however, it is still clear that the United States is underfunding its armed forces. 
Simply put, more money must be allocated to the US military. Rebalancing and costcutting can only take the Pentagon so far. Reduced budgets have wreaked havoc on not only the acquisition of new equipment, but on military readiness and capacity. Military leaders have repeatedly testified before congress to explain the continuing slide in military readiness. In fact, many feel that the military has been diminished to the point where it would not be able to fight a two-front war (Sullivan, 2016). Having the military on such bad footing not only reduces the credibility of American deterrence, but it, at the same time, would make it extremely difficult to maintain an Asian-Pacific alliance.

Another way to get more out of the military besides simply throwing more money at it (though this is needed), is to mix up the kinds of weapons that are being purchased. As we have seen, the new generation of weapons that the United States military is purchasing is mindbogglingly expensive. For the cost of only one new F35 stealth fighter, the military could purchase several older model fighter jets. And the new Gerald Ford class aircraft carriers being constructed by the navy are almost twice as expensive as their Nimitz class predecessors (Lockie, 2016). Clearly, the bleeding edge of military technology comes at a steep price, but is there a better way. It would be a mistake to simply say that advanced weapons are not needed or are too expensive. History has shown time and again that sometimes a technological edge over an enemy makes all the difference in a battle. This "quality over quantity" approach is one that has been adopted by the West for thousands of years. But as Stalin once remarked "quantity has a quality all its own."

The United States should continue to pursue the latest and greatest but, at the same time, must maintain a certain quantity of equipment as well. The quantity gaps left by the expense of new weapons might be filled in by less advanced but still very capable systems. This "high-low" 
approach has been discussed for some time in the military and is somewhat controversial (Newson, 2015). The concept can best be summed up in the brief anecdote of the diesel submarine. Diesel submarines are as old as submarines themselves, and for a long time, diesel was the only power plant available to submariners. But entering into the nuclear age, more advanced nuclear submarines supplanted and replaced their diesel cousins, at least in the arsenals of super powers. The United States decommissioned its last diesel submarine during the early 1990's. However, several European nations and Japan continued to build ever more sophisticated diesel submarines. These modern diesel boats, unlike their antiquated forerunners from the Second World War, have the ability to stay submerged for weeks at a time, a capability that was, until recently, only possessed by nuclear submarines. The US Navy, recognizing the proliferation of newer, stealthier diesel submarines, rented a state of the art diesel submarine from Sweden for testing in the United States.

What followed in ensuing war games shocked the US Naval establishment. The little ship evaded all attempts at locating it and scored many "kills" against aircraft carriers and other ships. The Navy found that where a nuclear submarine would have been detected, the diesel submarine slipped through defenses. The takeaway from the story is that not only are the diesel submarines more capable in certain situations than their nuclear counterparts, they are much more affordable. For the price of one nuclear submarine, five or more diesels can be purchased (Kazianis, 2016). Clearly, in an age of limited resources and cash, the United States could pad its forces with cheaper, but just as capable (and sometimes more capable) options.

If the United States wants to pivot to Asia, or ever build a resilient Asia-Pacific alliance, let alone balance against China, it needs to drastically reorient its priorities, spend more on its military, and spend that money smarter. These steps will relieve the strain on a force stretched 
thin while giving it a credible presence in the Asia-Pacific region. And if the US chooses to form or participate in an Asian-Pacific alliance, it will be able to do so without breaking the bank.

\section{The Nine Dash Solution}

It is clear that the contested lines which crisscross the South China Sea have created a diplomatic nightmare and a protracted problem for the nations involved. Each nation has overlapping, and sometimes even interchangeable, claims to the islets, rock features and seabed of the region. Any Asian-Pacific-based alliance with the objective of halting the territorial advance of China in the South China Sea, or balancing it in the region, would have to decide what belongs to each nation, and what is worth protecting. As their forbearers in the original European NATO did, Asian-Pacific NATO would have to decide what constitutes the sovereign territories which the alliance would actually defend.

Part of the answer to this complex question may lie in international law. The original NATO was, at first, a controversial organization. Some thought the organization undermined the legitimacy of the United Nations which had been founded in part to prevent war. However, from the very beginning, the founders of NATO always sought to base their actions and their legitimacy in the context of international law and the United Nations charter. Specifically, the founders rested the legitimacy of NATO within Article 51 of the United Nation Charter. Article 51 reaffirms the right of nations to defend themselves from attack both individually and collectively until the Security Council of the United Nation can restore peace. That is to say, that Article 51 explicitly recognizes the legitimacy of collective security organizations and alliances. With this legal justification, NATO framed its existence in terms of international law, thus legitimizing its creation and mission. The very language of the NATO treaty constantly refers back to the United Nations Charter, and speaks of the organization as if it is merely an extension 
of that global body. An Asian-Pacific alliance would do well to emulate the success of NATO by adopting and framing itself within current international law. The path to affirming its legitimacy under international law has already been blazed by a diverse number of collective defense pacts (MacCloskey, 1967). The real challenge for an Asian-Pacific alliance, would be parsing out the tangled lines in the South China Sea, but here, international law would be just as indispensable.

One of the greatest assets for an Asian-Pacific alliance would be the United Nations' Law of the Sea, which clearly describes the rights and privileges of those nations which border an ocean. Nations are entitled to a 12-mile sovereignty zone surrounding their land-mass, as well as a 200-mile economic exclusion zone. And while there are nations outside of China that have competing claims in the South China Sea, assent to international law and organizations has been affirmed by most, if not all, claimants in the region. Yet this assent does not seem to include China (PCA, 2016).

As we have already seen, China has violated the economic exclusion zone of the Philippines by constructing artificial islands within the 200-mile limit. This is a clear violation of international law, and an Asian-Pacific collective security organization would be on solid ground in demanding the removal of Chinese forces from artificial islands within the 200-mile exclusion zone.

Whether or not it would be appropriate to engage Chinese naval and marine forces in an Article 5-type defense on behalf of the Philippines, would be quite another thing. The AsiaPacific alliance might be best to adopt the policy of the original NATO and prevent China from acquiring further islands and territory. To do this, it must be made clear that any further action within the 200-mile exclusion zone would be considered a violation of Philippine sovereignty, triggering an alliance response. Drawing such a line is necessary for deterrence to have any 
substantive meaning. Deterrence exists for the purpose of deterring your adversary from taking certain unfavorable actions (Gaddis, 2005). If the hypothetical Asian-Pacific alliance did not make it clear that further incursions would not be tolerated, then all pretense of effective deterrent would go out the window.

An Asian-Pacific alliance would also be armed with the ruling of the Permanent Court of Arbitration. The Court, of which most countries surrounding the South China Sea are members (including China), took up the case of the Philippines, who protested the activities of China in the South China Sea. In a stunning ruling, the Court struck down the legitimacy of China's historical claim to the South China Sea. The nine-dash line has been delegitimized as a stake in the South China Sea. Furthermore, the Court reaffirmed the UN Law of the Sea by declaring that artificial islands, whether within the Philippine's 200-mile EEZ or in international waters, do not constitute a legitimate legal basis for sovereignty claims (PCA, 2016).

In the eyes of the law, China does not have a leg to stand on in the South China Sea debate. Just as Soviet occupation of the various Eastern European republics and countries was illegitimate, so, too, is China's occupation of marine features within the exclusive economic zones of surrounding countries. This must be the position of any potential Asian-Pacific alliance. Based itself in international law, an Asian-Pacific NATO must also appeal to and enforce that same international law. It must draw a line in the sand, freshly deposited on coral reefs, and declare that any further advances would be considered acts of aggression. If it does so, it not only greatly reduces the likelihood of conflict, but would fulfill the very purpose for which it was created. 


\section{Blow Back Solution}

A prospective Asian-Pacific alliance may overcome all of the preceding challenges and yet still be faced with the possibility of a strong or provocative Chinese response to the formation of an alliance, leading to a security dilemma. China may choose to restart and accelerate its island construction programs, or it could begin expanding military outside of the South China Sea region. It may also forge its own alliance by strengthening ties to Russia or other Central and Southeast Asian nations.

Of course, we have seen that NATO faced much the same problem with Soviet expansionism and the creation of the Warsaw pact. The creation of the Warsaw Pact was precipitated by the addition of West Germany to NATO. Yet, the addition of West Germany to NATO was seen by Western military strategists as absolutely essential to the defense of Europe. Provocative as it was, it was also necessary. Likewise, as provocative as an Asian-Pacific NATO-type alliance might be, it may be absolutely necessary to curtail the current belligerent actions of Beijing.

As NATO could do little to nothing to stop the formation of the Warsaw Pact, AsianPacific alliance planners would have no control over how China responds. They would, however, control their counter-response. NATO could never control the actions of Soviet Russia, it could only deter them. From Korea to Vietnam and Afghanistan, both global behemoths played a high stakes Chess game with many moves and counter moves. And, as in Chess, NATO and the West's ultimate mission was to checkmate the Soviet Union: to hem it in, until it had no more moves left to make. This strategy of containment was the overarching objective of the United States and NATO. The Soviet Union could not be allowed to expand any further. On every 
peninsula and in every backwater, the goal was always the same: halt the advance of Communism.

On every rocky shoal and submerged reef, the goal of Asian-Pacific NATO would be the same: halt the advance of an aggressive China. Justifying the need for the existence of an AsianPacific NATO is a challenge that can be overcome. Rewriting a constitution written by an occupying army is a challenge that can also be met. Restoring funding to the United States military and purchasing effective weaponry is a challenge easily overcome. Parsing out territorial lines and enforcing international law is also a surmountable challenge. These challenges are all, in actuality, the constituent steps to solving the real problem of an Asian-Pacific alliance:

Containment. It is the containment of China which is the real challenge for an Asian-Pacific NATO. But why come to this conclusion? It is, in fact, the same conclusion reached by the policy makers in Cold War Europe. 


\section{CHAPTER IV: DISCUSSION}

It is clear that both the original European NATO and our hypothetical Asian-Pacific NATO, have faced and would face many difficult challenges. Surprisingly, an Asian-Pacific NATO would be faced with many challenges that echo ones faced by its predecessor. Yet in other ways, the two could not be further apart. When we began this thesis, we asked kind of challenges a potential Asian-Pacific NATO-type alliance might face, now we will compare and contrast both the real-world NATO and our hypothetical Asian-Pacific NATO.

Beginning with a challenge that both alliances have in common is their need to justify their very existence. When NATO was created, it was done so with the express purpose of including the United States. Without such an inclusion, the Brussels Treaty would have been insufficient as a means of protecting the nations of Western Europe. Just as the Treaty of Brussels was insufficient to fully protect Western Europe, the hub and spoke system maintained by the United States, is also lacking in many ways. Specifically, it does not have the advantages that are inherent in a formal alliance system. It seems clear that, thus far, the current American lead pseudo-alliance has not checked the territorial advance of China in the South China Sea. In this respect, the hub and spoke system has demonstrated its inadequacy. It was clear, more than seventy years ago, that the Treaty of Brussels was insufficient for the defense of Europe. The answer then was clear: build an alliance. Today, it appears that the American lead coalition of alliances has not deterred the Chinese from their expansionism in the South China Sea. Furthermore, the leaders of Asia and America have not, as of yet, moved to enact a formal alliance. Perhaps, if events in the Asia-Pacific region continue to deteriorate, policy makers and political leaders, will come to the same conclusion as their European predecessors did. 
Should an Asian-Pacific NATO actually be formed, it would face a challenge strikingly familiar to the original NATO. Both alliances needed, and need the inclusion of controversial members. NATO needed to include West Germany in order to have sufficient man-power to protect Western Europe. This, unfortunately lead to the creation of the Warsaw Pact. Additionally, France withdrew from the alliance for a time damaging the image of unity that the defense pact had maintained. However, our Asian-Pacific NATO need not necessarily face these repercussions. It is unclear whether or not NATO could have mitigated or eliminated the fallout that occurred after West Germany was many a member. But if Japan were to be made a member of Asian-Pacific NATO, there are several very clear steps-like apologizing for past war crimesthat could pave the way for acceptance. Yet, unlike its West German predecessor, the path to rearmament is a more complicated one for Japan. Nevertheless, it is easy to see the parallels between the two cases and in looking to the past for lessons, an Asian-Pacific NATO could avoid or minimize the impact of the inclusion of Japan. But could the new alliance minimize financial costs?

Whether then or now, the cost of maintaining an alliance is very expensive. However, during the Cold War, the United States felt that this cost was worth it. Several strategies were employed in order to maintain the level of spending needed. But perhaps most importantly, the United States simply spent more than the Soviet Union could on defense. This financial brinksmanship was one of the primary reasons that the United States emerged as the eventual victor. Thus, the combined financial might of the members of an Asian-Pacific NATO would be best utilized by outspending their Chinese opponent in defense. Despite recent cutbacks, the United States still far outspends China on defense. Combined with Japan and several other 
wealthy nations, this difference would become dramatic. Doing so would mirror the strategy originally used to defeat the Soviet Union, while spreading costs between the members.

Though both alliances have many things in common, one of the most serious differences is territorial disputes. Simply put, there were very few, if any territorial disputes during the Cold War between the Soviet Union and NATO. In the South China Sea, the borders which are claimed by neighboring nations overlap each other in a complicated web. Deciding what belongs to whom and what to defend would certainly be a challenge. However, Asian-Pacific NATO might look to a somewhat dissimilar incident from the historical pages of NATO and the United States. During the Cuban Missile Crisis, the United States demanded the removal of nuclear weapons from the island of Cuba. Such weapons threatened the territorial integrity and security of the United States. However it was only after intense negotiations behind the scenes with the Soviet Union, and the removal of American missiles from Turkey that the crisis was averted. Such intensive negotiations and concessions may be needed in the South and East China Seas before any boundaries might be finalized. Doing so would allow an Asia-Pacific alliance to lower tensions and avoid an imminent conflict.

Finally, both alliances faced and may face the prospect of blowback. That is to say, significant consequences from the actions that they take. But, as we have seen with both alliances, this risk may be hard to eliminate. Undoubtedly there would come a time in the life of an Asian-Pacific NATO were its actions would be unacceptable to the Chinese. With the inclusion of West Germany into NATO, the Soviet Union responded by creating the Warsaw Pact. However, it is hard to see how NATO could have avoided this outcome. Not integrating West Germany was not an option. Sometimes, it is simply necessary to whether the storm. An Asian-Pacific alliance may make decisions which outrage the Chinese, but sometimes such 
decisions cannot be avoided. Japan, like West Germany, would be a controversial member of the Asian-Pacific Alliance. However, like West Germany, Japan is a prosperous and advanced nation, and an Asian-Pacific alliance could not afford to exclude it. Like its forbearer, an AsianPacific NATO might simply find that it is best to absorb the negative consequences rather than to capitulate to Chinese demands.

Clearly the challenges that confronted NATO and may confront an Asian-Pacific NATO are very similar. The original European NATO solved its challenges successfully and emerged from the Cold War as a victor. Likewise, an Asian-Pacific NATO could make use of many of the solutions used by the original NATO to tackle its challenges. But while both alliances were and may be confronted with challenges that are similar, the ultimate challenge for both was and is containment. The same solutions to NATO's challenges are very similar to those for AsianPacific NATO. Likewise, the strategy used for containment by NATO and the United States may still be relevant for an Asian-Pacific NATO today.

The tenets of Cold War containment policy were laid out in the now famous NSC-68 document. NSC-68 was an aggressive strategy that sought to block Soviet advances at every turn. The purpose was to delegitimize and block further Soviet expansionism, and, in the end, the plan worked. To meet the modern goal of containing Chinese expansionism, a revised NSC-68, would have to be drafted for the nascent Asian-Pacific defense pact. While the original threatthe Soviet Union-has long since disappeared, the steps used to contain it are still relevant to our Asian-Pacific NATO.

1) Block further Soviet (Chinese) expansion

No more Chinese maritime expansion must be allowed. A red line must be drawn corresponding to the 200-mile exclusive economic zones of the member countries of the 
Asian-Pacific alliance. It must be made clear that further expansion within these zones would activate the pact's defense mechanism and precipitate a military response. In the thin pocket of international water in the middle of the South China Sea, which is rimmed by the EEZs of surrounding countries, it must also be made clear that any Chinese islands constructed in that zone are not, under the Law of the Sea, considered sovereign territory. Nor do these sandy artifices entitle the builder to oceanic sovereignty or an EEZ zone as naturally occurring islands do. Building islands in international waters does not make those waters Chinese. Thus Chinese exclusion and air identification zones around those particular islands, would not be respected. Furthermore, the alliance might seek to build its own islands within such waters, so as to negate the Chinese military advantage and gain parity in capabilities. Clearly, solving one of the original challenges of defining Article 5 territory fits perfectly into a containment strategy.

\section{2) Expose the falsities of Soviet (Chinese) pretensions}

The pretensions, or claims, of the Chinese government to the entirely of the South China Sea must be continually rejected by the Asian-Pacific alliance. Furthermore, the foundations of these claims must be exposed as false. The law as it is today would be on the side of the alliance. The Permanent Court, to which China is a member, has rejected the validity of historical claims based on the nine-dash line. By this ruling, which the Chinese are obligated to respect, the nine-dash line no longer is a legal basis for constructing islands and claiming the sea. In addition, the United Nations Law of the Sea, which China has ratified, clearly makes Chinese actions within economic exclusion zones illegal. The defense pact must expose the baselessness of Chinese claims and, in the process, take away the moral high ground. 
3) Induce retraction of the Kremlin's (Chinese Politburo's) control and influence

One of the long-term goals of the alliance should not only be the denial of further expansion, but the withdrawal of Chinese forces from artificial islands within the 200-

mile EEZ. In addition, China's influence over and within other countries should be curtailed and countered. The original Soviet-Sino Split presented an incredible opportunity for American diplomacy and strategy. It was important to the United States to exploit the split between these two power centers and thus weaken the Soviet Union. But today, Russia and China ironically grow ever closer. Yet in some ways, they have been driven together. Policy makers might do better to focus less on Russia, whose modern power is a shadow of its past, and more on China, which is expanding both territorially and militarily. If a modern détente with Russia could be effected, it would do much to weaken China militarily and mitigate the possibility of blowback.

4) Foster seeds of destruction within the Kremlin (Chinese Politburo) so as to bring them to the point of modifying behavior into accord with generally accepted international standards

While "seeds of destruction" is somewhat ominous, the goal of bringing China into line with international norms is both desirable and necessary. China is not the only country with competing claims, but it is the only one which so flagrantly violates international law and state sovereignty. If China can be brought to the negotiating table and cease in its illegal activities, then an Asian-Pacific alliance would have accomplished its mission. The original NSC-68 described one of its goals as maintaining military superiority, but always keeping the door open to Soviet negotiation and conciliation. China should always be given the option to conform to international laws and norms. A seat should 
always be left open for them at the negotiating table. Doing so would help to foster a dialogue and pursue a peaceful resolution to the crisis.

Though the original NSC-68 was an American document, it stressed that its goals would require the "combined strength" of the United States and its allies to be accomplished. Without allies, containment would not work. And without a NATO-type alliance in Asia Pacific, containment there will not work, either. While our two NATO alliances find themselves in different centuries and on different continents, they are not that dissimilar. Both are tasked with balancing against a large and powers which were and are perceived to be aggressive. Not surprisingly, due to their similar missions, both alliances have similar challenges and similar solutions to those challenges. If an Asian-Pacific NATO is ever to be formed, it will be following a well-trodden path left by its successful and older predecessor. And if it can do that, it will be allied and armed with a winning strategy.

\section{Conclusion}

When we first began this thesis, we asked what kind of challenges would confront a hypothetical Asian-Pacific NATO. How would it be constructed and what kinds of strategic problems would it have to overcome to become as successful as its European counterpart. We can now see that not only are the challenges similar to the ones which the original European NATO faced, they are, in fact, surmountable. But even more than being surmountable, the challenges that we have reviewed are small in comparison to the ultimate challenge faced by an Asian-Pacific NATO: containment. Just the original NATO was tasked with containing the Soviet Union, an Asian NATO would be responsible for containing an increasingly expansionist China. 
This conclusion is firmly rooted in Structural Realist theory. The purpose of alliances according to Structural Realist theory, is to balance against rising powers and potential hegemons. China is clearly a rising power and potentially a rising hegemon. Many nations of the Asia-Pacific region view China's actions as hostile and unacceptable and may understandably feel threatened. Separately, there is little chance that they could hope to balance against China. But together, bound in an alliance, their combined weight might tip the scales. And, one of the most effective balancing strategies, as demonstrated by the original NATO is containment. If China continues to act aggressively in the eyes of its neighbors, and does not respond to international pressure, we might expect that the nations which feel threatened would band together in a NATO-type alliance. This response would almost be automatic since, according to Structural Realism, a change in the international structure-such as the rise of China-demands a response by surrounding states.

However, this conclusion may or may not come to pass, no matter what actions China takes. For one, events are still unfolding day by day. The situation in the South China Sea is very volatile, with many different actors, all with different and competing agendas. Perhaps Japan will sign a peace treaty with China, or the Philippines will negotiate a territorial bargain. Either way, the status quo is too fluid to effectively predict the future. Another limitation to this study is the theoretical framework itself. It may not be that the theory of Structural Realism best describes the situation in Asia, or that it even fully describes it. In fact, there are many different strands of Realism, let alone other theories. Defensive Realism, for example, may better describe the current environment and future developments. Other international theories, such as Liberalism, allow for institutions and norms to have a much greater impact on international affairs, than 
Realist theory allows. Perhaps this will be the case in the Asia-Pacific region. It may be that the United Nations or some other multilateral or international body finally solves the crisis.

With our findings and subsequent limitations in mind, we hope that future scholars will explore new avenues of research to determine the likelihood of an alliance system forming in the Asia-Pacific region. Different methodologies may also shed new light on the present situation and completely change our understanding of the region and its potential future. Hopefully, this paper has helped to break new ground. As we have seen, there is little to no current literature which covers the possibility of a defensive alliance in the Asian-Pacific Region. In the future, other authors may want to continue investigating this possibility in order to gauge its feasibility.

In any case, it is clear that the situation in the South and East China Seas will most likely remain relevant and in the headlines for many years to come. Hopefully these future developments will reflect an easing of tensions and a drawdown in military forces. Yet, should the situation continue to deteriorate, should China construct more islands or take what appears to be aggressive actions, we should not be surprised to see the formation of a powerful and modern Asian-Pacific alliance. 


\section{REFERENCES}

Albert, E. (2015). The Shanghai Cooperation Organization. Retrieved July 16, 2016 from The Council on Foreign Relations: http://www.cfr.org/china/shanghai-cooperationorganization/p10883

AMTI. (2015). Arbitration on the South China Sea: Rulings from The Hague. Retrieved July 7 , 2016 from Asia Maritime Transparency Initiative: https://amti.csis.org/ArbitrationTL/

ASEAN. (2016). History. Retrieved July 7, 2016 from ASEAN: http://asean.org/asean/aboutasean/history/

Bagbaslioglu, A. (2014). Relations with "Global Partners" in the Framework of NATO's New Partnership Policy. Security Strategies.

Baker, B. (2015). Where Is the 'String of Pearls' in 2015? Retrieved July 18, 2016 from The Diplomat: http://thediplomat.com/2015/10/where-is-the-string-of-pearls-in-2015/

Baltimore Sun. (1995). Showdown at Mischief Reef. Retrieved July 18, 2016 from Baltimore Sun: http://articles.baltimoresun.com/1995-08-05/news/1995217032_1_south-china-seaspratly-islands-mischief-reef

BBC. (2015). Japan and South Korea agree WW2 'comfort women' deal. Retrieved July 20, 2016 from BBC: http://www.bbc.com/news/world-asia-35188135

BBC. (2016). Fresh data confirms Chinese economic slowdown. Retrieved July 29, 2016 from BBC: http://www.bbc.com/news/business-35693794

BBC. (2016). The Great Chinese Crash. Retrieved July 30, 2016 from BBC this World : https://www.youtube.com/watch?v=uXVnoIThq-A

Beech, H. (2016). What a Retracted Statement Says About China's Growing Power in the South China Sea. Retrieved July 30, 2016 from Time: http://time.com/4369660/asean-southchina-sea-statement/

Beeson, M. (2016). Can ASEAN Cope with China? Journal of Current Southeast Asian Affairs, 5-28.

Bender, J. (2016). 15 of the most expensive projects abandoned by the US military. Retrieved July 5, 2016 from Business Insider: http://www.businessinsider.com/some-of-themilitarys-most-expensive-sunk-cost-projects-2016-1/\#future-combat-systems-1

Bergen, P. (2005). Blowback Revisited. Retrieved August 2, 2016 from Foreign Affairs: https://www.foreignaffairs.com/articles/afghanistan/2005-10-01/blowback-revisited

Bin, Y. (2016). China-Russia Relations: H-Bomb Plus THAAD Equals Sino-Russian Alliance? Comparative Connections, 127-137. 
Bisley, N. (2012). China's Rise and the Making of East Asia's Security Architecture. Journal of Contemporary China, 19-34.

Blair, D. (2001). From Wheels to Webs: Reconstructing Asia-Pacific Security. The Washington Quarterly, 7-17.

Borchers, H. (2014). ASEAN's Enviromental Challenges and Non-Traditional Security Cooperation: Towards a Regional Peacekeeping Force? Austrian Journal of South-East Asian Studies, 5-20.

Browne, A. (2015). For Japan, a Difficult Art of Saying It's Sorry. Retrieved June 22, 2016 from The Wall Street Journal: http://www.wsj.com/articles/for-japan-a-difficult-art-of-sayingits-sorry-1421127266

Burgess, S. (2016). Rising bipolarity in the South China Sea: the American rebalance to Asia and China's expansion. Contemporary Security Policy, 111-143.

Burrows, M. (2016). Is America Ready for a Multipolar World? Retrived June $17^{\text {th }}$, 2016 from The National Interest: doi:http://nationalinterest.org/feature/america-ready-multipolarworld-14964

Bush, R. C. (2015). As Cross Purposes. Abingdon: Routledge.

Capie, D. (2002). Withering Realism? A Review of Recent Security Studies on the Asia-Pacific Region. Institute of Southeast Asian Studies .

CFR. (2009). Tiananmen Square and Two Chinas. Retrieved July 15, 2016 from Council on Foreign Relations: http://www.cfr.org/china/tiananmen-square-two-chinas/p19544

CFR. (2016). China's Maritime Disputes . Retrieved July 5, 2016 from Council on Foreign Relations: http://www.cfr.org/asia-and-pacific/chinas-maritimedisputes/p31345\#!/p31345

Chamberlain, N. (1938). Peace For Our Time. Munich Agreement. Great Britain.

Chang, G. (2013). China and the Biggest Territory Grab Since World War II. Retrieved July 27, 2016 from Forbes: http://articles.baltimoresun.com/1995-0805/news/1995217032_1_south-china-sea-spratly-islands-mischief-reef

Chia, S. (2015). ASEAN Economic Cooperation and Integration. Cambridge: Cambridge University Press.

Churchill, W. (1946). Iron Curtain Speech.

CIA. (2016). Japan. Retrieved June15, 2016 from Central Intelligence Agency: https://www.cia.gov/library/publications/the-world-factbook/geos/ja.html

CISIS. (2016). How does China's first. Retrieved June 14, 2016 from Center for Strategic and International Studies: http://chinapower.csis.org/aircraft-carrier/ 
CNAS. (2016). TIMELINE: 1955-PRESENT. Retrieved June 8, 2016 from Center for New American Security: http://www.cnas.org/flashpoints/timeline

Dalpino, C. (2013). Special Assessment: Asian Regionalism Multilateralism in the Asia-Pacific. Comparative Connections: A Triannual E-Journal on East Asian Bilateral , 149-157.

Davidson, J. (2015). How the Overseas Contingency Operations Fund Works-and Why Congress Wants to Make It Bigger. Retrieved July 20, 2016 from Council on Foreign Relations : http://blogs.cfr.org/davidson/2015/06/16/how-the-overseas-contingencyoperations-fund-works-and-why-congress-wants-to-make-it-bigger/

Denyer, S. (2016). Beijing's claims to South China Sea rejected by international tribunal. Retrieved July 24, 2016 from The Washington Post: https://www.washingtonpost.com/world/beijing-remains-angry-defiant-and-defensive-askey-south-china-sea-tribunal-ruling-looms/2016/07/12/11100f48-4771-11e6-8dac0c6e4accc5b1_story.html

Dian, M. (2014). The Evolution of the US-Japan Alliance. Boston: Chandos Publishing .

Donnini, F. (1991). Anzus in Revision. Maxwell Airforce Base : Air University Press.

Duffield, J. (1995). NATO's Functions After the Cold War. Political Science Quarterly, 763 787.

Duignan, P. (2000). NATO: Its Past, Present, and Future. Stanford: Hoover Institution Press.

Evans, P. (2001). Cooperative Security and Its Discontents in Asia Pacific: The ASEAN Connection. American Asian Review, 99.

Fallon, T. (2013). NATO and Its Limits in the Asia-Pacific. China Brief, 8-11.

Fenton, D. (2012). To Cage the Red Dragon. Singapore: NUS Press.

Fiammenghi, D. (2011). The Security Curve and the Structure of International Politics. International Security, 126-154.

Fox News. (2016). Army has fewest active-duty soldiers since 1940, report says. Retrieved July 20, 2016 from Fox News : http://www.foxnews.com/politics/2016/05/09/army-hasfewest-active-duty-soldiers-since-1940-report-says.html

FPI. (2016). THE OBAMA ADMINISTRATION'S PIVOT TO ASIA. Retrieved from The Foreign Policy Initiative: http://www.foreignpolicyi.org/content/obama-administrations-pivot-asia

Francia, L. (2013). History of the Philippines: From Indios Bravos to Filipinos. New York City: The Overlook Press.

Friedberg, A. L. (2012). Bucking Beijing. Retrieved June 23, 2016 from Foreign Affairs: https://www.foreignaffairs.com/articles/china/2012-08-18/bucking-beijing

Gaddis, J. L. (1998). We Now Know. Oxford: Oxford University Press. 
Gaddis, J. L. (2005). Strategies of Containment. New York: Oxford University Press.

Gamble, M. (2016). Japan's Lethal 'Helicopter-Destroyer': An Aircraft Carrier in Disguise? Retrieved July 7, 2016 from The National Interest: http://nationalinterest.org/blog/thebuzz/japans-lethal-helicopter-destroyer-aircraft-carrier-disguise-15740

Goo, Y. (2014). Military Alliances and Reality of Regional Integration: Japan, South Korea, the US vs. China, North Korea. Journal of Economic Integration, 329-342.

Gould, J. (2015). Lawmakers Look for \$5 Billion Defense Cut. Retrieved July 20, 2016 from Defense News: http://www.defensenews.com/story/defense/policybudget/budget/2015/10/28/lawmakers-look-5-billion-defense-cut/74755966/

Haddick, R. (2014). Fire on the Water: China, America, and the Future of the Pacific. Annapolis: Naval Institute Press.

Harris, G. (2016). Vietnam Arms Embargo to Be Fully Lifted, Obama Says in Hanoi. Retrieved June 5, 2016 from New York Times: http://www.nytimes.com/2016/05/24/world/asia/vietnam-us-arms-embargoobama.html?_r=0

Hemmer, C. (2002). Why is There No NATO in Asia? Collective Identity, Regionalism, and the Orgins of Multilateralism. International Organization, 575-607.

Heydarian, R. (2016). Why the New US-Philippine Defense Pact Could Be a Double-Edged Sword. Retrieved June 27, 2015 from The Diplomat: http://thediplomat.com/2016/01/why-the-new-us-philippine-defense-pact-could-be-adouble-edged-sword/

Himmelman, J. (2016). A Game of Shark and Minnow. Retrieved July 11, 2016 from The New York Times: http://www.nytimes.com/newsgraphics/2013/10/27/south-china-sea/

Hong, Z. (2010). Energy Security Concerns of China and ASEAN: Trigger for Conflict or Cooperation in the South China Sea? East Asian Research Institute, 413-426.

Horvath, A. (2015). Beijing's Top Envoy Warns U.S. Against 'Anti-China' Alliances. Retrieved June 10, 2016 from Wall Street Journal: http://www.wsj.com/articles/beijings-top-envoywarns-u-s-against-anti-china-alliances-1432872322

Hughes, C. (2015). Japan's Foreign and Security Policy Under the "Abe Doctrine". New York: Palgrave Macmillian.

Jacobson, L. (2015). Anatomy of a talking point: the smallest Navy since 1917. Retrieved July 25, 2016 from Politifact: http://www.politifact.com/truth-ometer/article/2015/aug/03/anatomy-talking-point-navy-ship-counts-1917-and-/

Jagtiani, S. (2013). HITS AND MISSES: ASEAN AND REGIONAL SECURITY SOUTHEAST ASIA. Harvard Asia Quarterly, 73-79. 
Kai, H. (2012). 'Why is there no NATO in Asia?' revisited: Prospect theory, balance of threat, and US alliance strategies. European Journal of International Relations, 227-250.

Kazianis, H. (2016). This Could 'Sink' the U.S. Navy: Lethal Stealth Submarines. Retrieved August 3, 2016 from The National Interest: http://nationalinterest.org/blog/thebuzz/could-sink-the-us-navy-lethal-stealth-submarines-15034

Keay, J. (2011). China: A History. New York City: Baisic Books.

Keck, Z. (2015). China's Worst Nightmare? Japan May Sell India Six Stealth Submarines. Retrieved August 4, 2016 from The National Interest: http://nationalinterest.org/blog/chinas-worst-nightmare-japan-may-sell-india-six-stealth12149

Kelly, R. (2015). American Dual Containment in Asia. Geopolitics , 705-725.

Kelly, T. (2016). How France sank Japan's $\$ 40$ billion Australian submarine dream. Retrieved August 4, 2016 from Reuters: http://www.reuters.com/article/us-australia-submarinesjapan-defence-in-idUSKCNOXQ1FC

Khan, M. (2014). Pakistan-Iran-China Triangle: A Game Changer in the Region? Dialogue, 115138.

Kim, E. (1998). The Four Asian Tiger: Economic Development and the Global Political Economy. Cambridge: Academic Press.

Koga, K. (2011). The US and East Asian Regional Security Architecture: Building a Regional Security Nexus on Hub-and-Spoke. Asian Perspective , 1-36.

Kottasova, I. (2016). These NATO countries are not spending their fair share on defense. Retrieved July 29, 2016 from CNN Money: http://money.cnn.com/2016/07/08/news/natosummit-spending-countries/

Limsira, P. (2014). Thailand as an ASEAN-China Coordinator Country on the South China Sea Disputes. JOURNAL OF EAST ASIA AND INTERNATIONAL LAW, 554-560.

Lockie, A. (2016). America's most expensive warship ever built will undoubtedly change naval warfare. Retrieved August 5, 2016 from Business Insider: http://www.businessinsider.com/ford-class-aircraft-carrier-2016-6/\#new-reactor-and-anall-electric-ship-1

Lofflmann, G. (2016). The Pivot between Containment, Engagement, and Restraint: President Obama's Conflicted Grand Strategy in Asia. Asian Security, 92-110.

Londoño, E. (2013). Study: Iraq, Afghan war costs to top $\$ 4$ trillion. Retrieved July 25, 2016 from The Washington Post: https://www.washingtonpost.com/world/nationalsecurity/study-iraq-afghan-war-costs-to-top-4-trillion/2013/03/28/b82a5dce-97ed-11e2814b-063623d80a60_story.html

MacCloskey, M. (1967). Pacts for Peace. New York City: Richards Rosen Press. 
Macias, A. (2014). The 35 Most Powerful Militaries In The World. Retrieved July 25, 2016 from Business Insider: http://www.businessinsider.com/the-worlds-most-powerful-militaries2014-12

Maher, R. (2016). The Rise of China and the Future of the Atlantic Alliance. Foreign Policy Institute, 366-381.

Manchester, W. (2013). The Last Lion: Winston Spencer Churchill: Defender of the Realm, 1940-1965. New York City: Bantam.

Mastney, V. (2006). War Plans and Alliances in the Cold War. Abington: Routledge.

Matthews, C. (2016). Why China's Stimulus Package Was a Big Mistake. Retrieved August 10, 2016 from Fortune: http://fortune.com/2016/01/15/why-chinas-stimulus-package-was-abig-mistake/

McDevitt, M. (2016). Analysis: Is it Time for the U.S. to Take a Position on Scarborough Shoal? Retrieved July 22, 2016 from USNI: https://news.usni.org/2016/07/19/take-positionscarborough-shoal

Mearsheimer, J. (2001). The Tradgedy of Great Power Politics. New York: W.W. Norton \& Company .

Mie, A. (2016). Security laws usher in new era for pacifist Japan. Retrieved July 4, 2016 from Japan Times: http://www.japantimes.co.jp/news/2016/03/29/national/politicsdiplomacy/japans-contentious-new-security-laws-take-effect-paving-way-collective-selfdefense/\#.V7ZPxpgrJhE

Mirski, S. (2015). Dispute in South China Sea: a legal primer. Retrieved October 15, 2016 from LawFare: https://www.lawfareblog.com/dispute-south-china-sea-legal-primer

Mowle, T. (2007). The Unipolar World: An Unbalanced Future. Basingstoke: Palgrave Macmillan.

Nair, D. (2008). Regionalism in the Asia Pacific/East Asia: A Frustrated Regionalism? Contemporary Southeast Asia, 110-142.

NATO. (2015). Standardization . Retrieved August 10, 2016 from NATO: http://www.nato.int/cps/en/natohq/topics_69269.htm

Navarro, P. (2015). Crouching Tiger. Amherst: Prometheus Books.

Navarro, P. (2015). Crouching Tiger: What China's Militarism Means for the World. Amherst: Prometheus Books.

Newson, R. (2015). This Is What a Twenty-First Century U.S. Naval Strategy Looks Like. Retrieved July 21, 2016 from Council on Foreign: http://blogs.cfr.org/davidson/2015/05/13/this-is-what-a-twenty-first-century-u-s-navalstrategy-looks-like/ 
Oberdorfer, D. (2013). The Two Koreas: A Contemporary History. New York City : Basic Books.

Oberdorfer, D. (2013). The Two Koreas: A Contemporary History. New York City: Basic Books.

Oegroseno, A. (2013). ASEAN as the Most Feasible Forum to Address the South China Sea Challenges. American Society for International Law, 290-293.

onlinecitizen. (2016). Nine-Dash Line. Retrieved August 1, 2016 from http://www.theonlinecitizen.com/wp-content/uploads/2016/07/chinamap-claims450x401.png

Osborne, M. (2013). Southeast Asia: An Introductory History. Crows Nest: Allen \& Unwin.

Osnos, E. (2015). Age of Ambition: Chasing Fortune, Truth, and Faith in the New China. New York City: Farrar, Straus and Giroux.

Page, J. (2016). China, Russia set up for naval war games in South China Sea. Retrieved August 1, 2016 from The Wall Street Journal: http://www.theaustralian.com.au/business/wallstreet-journal/china-russia-set-up-for-naval-war-games-in-south-china-sea/newsstory/fd17160956a793719199e3b9cd10124d

Palatino, M. (2015). ASEAN's Joint Communique: It's Not Just About China or the South China Sea. Retrieved June 27, 2016 from The Diplomat:

http://thediplomat.com/2015/08/aseans-joint-communique-its-not-just-about-china-orthe-south-china-sea/

Panda, A. (2016). South China Sea: China Has Deployed Anti-Ship Missiles on Woody Island. Retrieved June 28, 2016 from The Diplomat: http://thediplomat.com/2016/03/southchina-sea-china-has-deployed-anti-ship-missiles-on-woody-island/

Parameswaran, P. (2015). The Truth About Philippine Military Modernization and the 'China Threat'. Retrieved July15, 2016 from The Diplomat: http://thediplomat.com/2015/07/thetruth-about-philippine-military-modernization-and-the-china-threat/

Park, J. J. (2011). The US-led alliances in the Asia-Pacific: hedge against potential threats or an undesirable multilateral security order? The Pacific Review, 137-158.

Parrikar, M. (2016). Managing Military Competition in Asia: Manohar Parrikar. Retrieved July16, 2016 from IISS: https://www.iiss.org/en/events/shangri\%20la\%20dialogue/archive/shangri-la-dialogue2016-4a4b/plenary2-e480/parrikar-5b41

PCA. (2016, July 12). The Republic of the Philippines vs. The Peoples Republic of China. Permanent Court of Arbitration .

Pettinger, T. (2012). External Costs. Retrieved August 15, 2016 from Economics help: http://www.economicshelp.org/blog/glossary/external-costs/ 
Phillips, T. (2016). Beijing rejects tribunal's ruling in South China Sea case. Retrieved September 19, 2016, from The Guardian:

https://www.theguardian.com/world/2016/jul/12/philippines-wins-south-china-sea-caseagainst-china

Port, K. (2009). Transcending Law: The Unintended Life of Article 9 of the Japanese Constitution. Durham: Carolina Academic Press.

PRC. (2016, July 12). Statement of the Ministry of Foreign Affairs of the People's Republic of China on the Award of 12 July 2016 of the Arbitral Tribunal in the South China Sea Arbitration Established at the Request of the Republic of the Philippines. Retrieved September 26, 2016, from The South China Sea Issue: http://www.fmprc.gov.cn/nanhai/eng/snhwtlcwj_1/t1379492.htm

Rapoza, K. (2015). Russia, China Get Energy Deals Under Way. Retrieved August 10, 2016 from Forbes: http://www.forbes.com/sites/kenrapoza/2015/06/03/russia-china-getenergy-deals-under-way/\#5d97c927477a

Reuters. (2016). apan's Abe makes offering at shrine to war dead, prompting China rebuke. Retrieved July 29, 2016 from Reuters: http://www.reuters.com/article/us-japan-yasukuniidUSKCN0XI050

Rolfe, J. (2008). Regional Security for the Asia-Pacific: Ends and Means. Contemporary Southeast Asia , 99-117.

Rozman, G. (2011). Chinese Strategic Thinking on Multilateral Regional Security in Northeast Asia. Orbis, 298-313.

Russett, B. (1998). Courting Disaster: An Expanded NATO vs. Russia and China. Political Science Quarterly, 361-382.

Schmitt, G. (2006, Dec 11). A NATO for Asia. Retrieved from The Weekly Standard : http://www.weeklystandard.com/a-nato-for-asia/article/14162

Scott, D. (2016). NATO and Japan: A strategic convergence? Post cold-war geopolitics: Russia, China, anti-piracy and anti-terrorism. International Politics, 324-342.

Sekiguchi, T. (2015). Japan to Provide Patrol Vessels to Philippines. Retrieved June 25, 2016 from Wall Street Journal: http://www.wsj.com/articles/japan-to-provide-patrol-vessels-tophilippines-1433424771

Seng, S. (2015). Seeking Stability in Turbulent Times: Southeast Asia's New Normal? Southeast Asian Affairs , 3-24.

Simon, S. (2016). US-Southeast Asia Relations: ASEAN Centrality? Comparative Connections: A Triannual E-Journal on East Asian Bilateral Relations, 45-54.

Smith, C. (2016). China's currency devaluation is just getting started. Retrieved August 16, 2016 from Business Insider: http://www.businessinsider.com/china-currency-devaluation-just- 
getting-started-2016-2http://www.businessinsider.com/china-currency-devaluation-justgetting-started-2016-2

Smith, N. (2016). Why US companies have started fleeing China. Retrieved August 16, 2016 from New York Post: http://nypost.com/2016/05/17/why-us-companies-have-startedfleeing-china/

Spalding, E. (2006). The First Cold Warrior. Lexington: University Press of Kentucky.

Starr, B. (2009). Sub collides with sonar array towed by U.S. Navy ship. Retrieved June 14, 2016 from CNN: http://www.cnn.com/2009/US/06/12/china.submarine/

State Department. (2016). Foreign Military Financing Account Summary. Retrieved July 7, 2016 from Department of State: http://www.state.gov/t/pm/ppa/sat/c14560.htm

Sugita, Y. (2003). Pitfall or Panacea. New York : Routledge.

Sullivan, J. (2016). America's Military Is in Much Worse Shape Than You'd Think. Retrieved July 15, 2016 from The Daily Signal: http://dailysignal.com/2016/03/25/americasmilitary-is-in-much-worse-shape-than-youd-think/

Taylor, A. (2015a). Map: The U.S. is bound by treaties to defend a quarter of humanity. Retrieved July 6, 2016 from The Washington Post: https://www.washingtonpost.com/news/worldviews/wp/2015/05/30/map-the-u-s-isbound-by-treaties-to-defend-a-quarter-of-humanity/

Taylor, A. (2015b). Putin may hate it, but NATO may be about to expand again. Retrieved July 7, 2016 from The Washington Post: https://www.washingtonpost.com/news/worldviews/wp/2015/10/15/putin-may-hate-itbut-nato-may-be-about-to-expand-again/

Tellis, A. (2013). Balancing without Containment: A U.S. Strategy for Confronting China's Rise. The Washington Quarterly, 109-124.

Thayer. (2016a). Revealed: The Truth Behind ASEAN's Retracted Kunming Statement. Retrieved July 14, 2016 from The Diplomat: http://thediplomat.com/2016/06/revealed-the-truthbehind-aseans-retracted-kunming-statement/

Thayer. (2016b). Southeast Asia's Regional Autonomy Under Stress. Southeast Asian Affairs, 318.

Thayer, C. (2013). ASEAN, China and the Code of Conduct in the South China Sea. SAIS Review of International Affairs, 75-84.

Thies, W. (2003). Friendly Rivals: Bargaining and Burden-Shifting in NATO. Armonk: Routledge.

TOW, W. (2009). Rules of engagement: America's Asia-Pacific security policy under an Obama administration. Australian Journal of International Affairs , 443-457. 
UMBC. (2016). Japanese War Crimes . Retrieved from University of Maryland, Baltimore: http://www.csee.umbc.edu/ kunliu1/Nanjing_Massacre.html

Walker, B. (2015). A Concise History of Japan . Cambridge: Cambridge University Press.

Walker, D. (2014). Trends in U.S. Military Spending. Retrieved July 13, 2016 from CFR: http://www.cfr.org/defense-budget/trends-us-military-spending/p28855

Walt, S. (1987). Alliances: Ballancing and Bandwagoning.

Waltz, K. (1979). Theory of International Politics. New York City: McGraw-Hill.

Weeks, D. (2011). An East Asian Security Community: Japan, Australia and Resources as 'Security'. Australian Journal of International Affairs , 61-80.

Weissman, M. (2010). THE SOUTH CHINA SEA CONFLICT AND SINO-ASEAN RELATIONS: A STUDY IN CONFLICT PREVENTION AND PEACE BUILDING. ASIAN PERSPECTIVE, 35-69.

Wiser, D. (2015). U.S. Military No Longer Able to Fight Two Wars at Same Time. Retrieved July 26, 2016 from The Washington Free Beacon: http://freebeacon.com/national-security/u-smilitary-no-longer-able-to-fight-two-wars-at-same-time/

WONG, C. H. (2016). Maritime Spat Simmers as U.S., China Talk. Retrieved July 5, 2016 from The Wall Street Journal: http://www.wsj.com/articles/u-s-china-trade-barbs-over-southchina-sea-at-shangri-la-dialogue-1465133442

Wong, P. (2014). U.S. China Containment and Counter-Containment in Southeast Asia. African and Asian Studies, 33-58.

Woo, Y. (2016). Abe's distortion over comfort women recurs. Retrieved June 24, 2016 from The Korea Times: http://www.koreatimes.co.kr/www/news/nation/2016/08/120_195814.html

Wudunn, S. (1995). Japanese Apology for War Is Welcomed and Criticized. Retrieved June 24, 2016 from New York Times: http://www.nytimes.com/1995/08/16/world/japaneseapology-for-war-is-welcomed-and-criticized.html

Yan, S. (2015). Hundreds arrested as Beijing launches stock market crackdown. Retrieved August 11, 2016 from CNN Money: http://money.cnn.com/2015/08/31/investing/chinaarrests-markets-crash/

Yergin, D. (2013). Congratulations, America. You're (Almost) Energy Independent. Retrieved August 14, 2016from Politico:

http://www.politico.com/magazine/story/2013/11/congratulations-america-youre-almostenergy-independent-now-what-098985

Zoroya, G. (2016). 20 veterans a day committed suicide in 2014, new data show. Retrieved July 23, 2016 from USA Today: http://www.usatoday.com/story/news/nation/2016/07/07/veterans-suicides-young-menwomen/86755132/ 